\title{
Outcome of hematopoietic cell transplantation for DNA double-strand break repair disorders
}

\section{Slack, James}

2018-01

Slack, J , Albert , M H, Balashov, D , Belohradsky, B H, Bertaina , A, Bleesing , J , Booth , C , Buechner , J , Buckley , R H, Ouachee-Chardin, M, Deripapa, E, Drabko , K, Eapen , M , Feuchtinger , T , Finocchi , A, Gaspar , H B , Ghosh , S, Gillio , A, Gonzalez-Granado , L I , Grunebaum , E , Gungor , T , Heilmann , C , Helminen, M , Higuchi , K, Imai , K, Kalwak, K, Kanazawa , N, Karasu , G, Kucuk , Z Y, Laberko , A, Lange , A, Mahlaoui , N , Meisel , R, Moshous , D , Muramatsu , H, Parikh , S , Pasic , S , Schmid , I , Schuetz , C , Schulz, A, Schultz , K R , Shaw , P J , Slatter , M A , Sykora , K-W , Tamura , S, Taskinen , M , Wawer , A , Wolska-Kusnierz, B , Cowan , M J , Fischer , A, European Soc Blood Marrow , European Soc Immunodeficiencies, Stem Cell Transplant, Ctr Int Blood Marrow \& Primary Immunodeficiency Treatment 2018, ' Outcome of hematopoietic cell transplantation for DNA double-strand break repair disorders ' , Journal of Allergy and Clinical Immunology , vol. 141 , no. 1 , pp. 322-+ . https://doi.org/10.1016/j.jaci.2017.02.036

http://hdl.handle.net/10138/298620

https://doi.org/10.1016/j.jaci.2017.02.036

publishedVersion

Downloaded from Helda, University of Helsinki institutional repository.

This is an electronic reprint of the original article.

This reprint may differ from the original in pagination and typographic detail.

Please cite the original version. 


\title{
Outcome of hematopoietic cell transplantation for DNA double-strand break repair disorders
}

\author{
James Slack, MD, ${ }^{a}$ Michael H. Albert, MD, ${ }^{b}$ Dmitry Balashov, PhD, ${ }^{\mathrm{c}}$ Bernd H. Belohradsky, MD, ${ }^{\mathrm{b}}$ Alice Bertaina, PhD, ${ }^{\mathrm{d}}$ \\ Jack Bleesing, PhD, ${ }^{\mathrm{e}}$ Claire Booth, PhD, ${ }^{\mathrm{f}}$ Jochen Buechner, PhD, ${ }^{\mathrm{g}}$ Rebecca H. Buckley, MD, ${ }^{\mathrm{h}}$ Marie Ouachée-Chardin, MD, \\ Elena Deripapa, MD, ${ }^{c}$ Katarzyna Drabko, MD, ${ }^{j}$ Mary Eapen, MD, ${ }^{k}$ Tobias Feuchtinger, MD,' Andrea Finocchi, PhD, ${ }^{\text {nn }}$ \\ H. Bobby Gaspar, PhD, ${ }^{\mathrm{f}}$ Sujal Ghosh, MD, ${ }^{\text {, } m}$ Alfred Gillio, MD, ${ }^{n}$ Luis I. Gonzalez-Granado, MD, ${ }^{\circ}$ Eyal Grunebaum, MD, ${ }^{p}$ \\ Tayfun Güngör, MD, ${ }^{9}$ Carsten Heilmann, MD, ${ }^{r}$ Merja Helminen, PhD, ${ }^{\text {s }}$ Kohei Higuchi, MD, ${ }^{t}$ Kohsuke Imai, PhD, ${ }^{4}$ \\ Krzysztof Kalwak, MD, ${ }^{v}$ Nubuo Kanazawa, PhD, ${ }^{\text {w }}$ Gülsün Karasu, MD, ${ }^{\mathrm{x}}$ Zeynep Y. Kucuk, MD, ${ }^{\mathrm{e}}$ Alexandra Laberko, MD, ${ }^{\mathrm{c}}$ \\ Andrzej Lange, MD, ${ }^{\mathrm{y}}$ Nizar Mahlaoui, MD, ${ }^{\text {,aa }}$ Roland Meisel, MD, ${ }^{\mathrm{m}}$ D. Moshous, PhD, ${ }^{\text {aa }}$ Hideki Muramatsu, PhD, \\ Suhag Parikh, MD, ${ }^{\circ}$ Srdjan Pasic, PhD, ${ }^{\text {cc }}$ Irene Schmid, MD, ${ }^{\text {b }}$ Catharina Schuetz, PhD, ${ }^{\text {dd }}$ Ansgar Schulz, MD, ${ }^{\text {dd }}$ \\ Kirk R. Schultz, MD, ${ }^{\text {ee }}$ Peter J. Shaw, MD, ${ }^{\text {ff }}$ Mary A. Slatter, MD, ${ }^{\text {a,gg }}$ Karl-Walter Sykora, PhD, ${ }^{\text {hh }}$ Shinobu Tamura, PhD, ${ }^{\text {ii }}$ \\ Mervi Taskinen, MD,ij Angela Wawer, MD, ${ }^{\text {kk }}$ Beata Wolska-Kusnierz, PhD," Morton J. Cowan, MD, ${ }^{\text {mm }}$ \\ Alain Fischer, $\mathrm{PhD}{ }^{\text {aa }}$ and Andrew R. Gennery, MD, ${ }^{\text {a,gg }}$ on behalf of the Inborn Errors Working Party of the European \\ Society for Blood and Marrow Transplantation and the European Society for Immunodeficiencies, Stem Cell Transplant \\ for Immunodeficiencies in Europe (SCETIDE), the Center for International Blood and Marrow Transplant Research, and \\ the Primary Immunodeficiency Treatment Consortium \\ Newcastle upon Tyne and London, United Kingdom; \\ Munich, Tübingen, Düsseldorf, Ulm, and Hannover, Germany; Moscow, Russia; Rome, Italy, Cincinnati, Ohio; Oslo, Norway; Durham, NC; \\ Paris, France; Lublin, Wroclaw, and Warsaw, Poland; Milwaukee, Wis; Hackensack, NJ; Madrid, Spain; Toronto, Ontario, and Vancouver, \\ British Columbia, Canada; Zurich, Switzerland; Copenhagen, Denmark; Tampere and Helsinki, Finland; Osaka, Tokyo, Wakayama, and \\ Nagoya, Japan; Istanbul, Turkey; Belgrade, Serbia; Westmead, Australia; and San Francisco, Calif
}

Background: Rare DNA breakage repair disorders predispose to infection and lymphoreticular malignancies. Hematopoietic cell transplantation (HCT) is curative, but coadministered chemotherapy or radiotherapy is damaging because of systemic radiosensitivity. We collected HCT outcome data for Nijmegen breakage syndrome, DNA ligase IV deficiency, CernunnosXRCC4-like factor (Cernunnos-XLF) deficiency, and ataxiatelangiectasia (AT).

Methods: Data from 38 centers worldwide, including indication, donor, conditioning regimen, graft-versus-host disease, and

\footnotetext{
From ${ }^{\text {a }}$ the Institute of Cellular Medicine, Newcastle University, Newcastle upon Tyne; ${ }^{b}$ Dr. von Hauner University Children's Hospital, Ludwig-Maximilians-Universität, Munich; 'the Immunology and Hematopoietic Stem Cell Transplantation Department, Federal Research Center for Pediatric Hematology, Oncology and Immunology, Moscow; dhe Stem Cell Transplant Unit, Department of Hematology and Oncology, Ospedale Pediatrico Bambino Gesù, Rome; ${ }^{\mathrm{e}}$ the Division of Bone Marrow Transplantation and Immune Deficiency, Department of Pediatrics, Cincinnati Children's Hospital Medical Center, University of Cincinnati; ${ }^{\mathrm{f}}$ Infection, Immunity, Inflammation, Molecular and Cellular Immunology Section, UCL Great Ormond Street Institute of Child Health, London; ${ }^{g}$ the Department of Pediatric Hematology and Oncology, Oslo University Hospital, Oslo; ${ }^{\mathrm{h}}$ Duke University School of Medicine, Departments of Pediatrics and Immunology, Duke University Medical Center, Durham; ${ }^{i}$ the Paediatric BMT Unit, Robert Debre Hospital, Paris; ${ }^{j}$ the Department of Pediatric Hematology, Oncology and Bone Marrow Transplantation, Medical University of Lublin; ${ }^{k}$ the Center for International Blood and Marrow Transplant Research, Division of Hematology/Oncology, Department of Medicine, Medical College of Wisconsin, Milwaukee; the Department of Haematology and Oncology, University Children's Hospital Tübingen; ${ }^{m}$ the Division of Pediatric Stem Cell Therapy, Department of Pediatric Oncology, Hematology and Clinical Immunology, Medical Faculty, Center of Child and Adolescent Health, Heinrich-Heine-University,

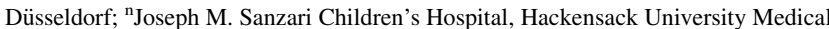
Center, Hackensack; ${ }^{\circ}$ the Immunodeficiencies, Hematology \& Oncology Unit, Pediatrics, Hospital 12 Octubre, and Universidad Complutense, Instituto de Investigación

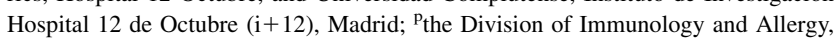
Hospital for Sick Children, University of Toronto; ${ }^{\mathrm{q}}$ the Division of Stem Cell Transplantation, University Children's Hospital Zürich; ' BørneUngeKlinikken, Copenhagen; 'the Paediatric Research Center, University Hospital of Tampere; 'Osaka Medical Center and Research Institute for Maternal and Child Health; "the Department
}

outcome, were analyzed. Conditioning was classified as myeloablative conditioning (MAC) if it contained radiotherapy or alkylators and reduced-intensity conditioning (RIC) if no alkylators and/or $150 \mathrm{mg} / \mathrm{m}^{2}$ fludarabine or less and $40 \mathrm{mg} / \mathrm{kg}$ cyclophosphamide or less were used.

Results: Fifty-five new, 14 updated, and 18 previously published patients were analyzed. Median age at HCT was 48 months (range, 1.5-552 months). Twenty-nine patients underwent transplantation for infection, 21 had malignancy, 13 had bone marrow failure, 13 received pre-emptive transplantation, 5 had

of Community Pediatrics, Perinatal and Maternal Medicine, Tokyo Medical and Dental University; " the Department of Pediatric Hematology, Oncology and BMT, Wroclaw Medical University; the Departments of ${ }^{\mathrm{w}}$ Dermatology and ${ }^{\mathrm{ii}}$ Hematology and Oncology, Wakayama Medical University; ${ }^{\mathrm{x}}$ Bahcesehir University Faculty of Medicine, Göztepe Medicalpark Hospital Pediatric Stem Cell Transplantation Unit, Istanbul; ${ }^{y}$ Hirszfeld Institute of Immunology and Experimental Therapy, Polish Academy of Sciences / Lower Silesian Center for Cellular Transplantation, Wrocław; ${ }^{\mathrm{z}}$ the French National Reference Center for Primary Immune Deficiencies (CEREDIH), Necker Enfants Malades University Hospital, Assistance Publique-Hôpitaux de Paris; ${ }^{a}$ the Immuno-Hematology Unit, Necker Children's Hospital, Assistance Publique

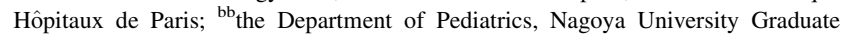
School of Medicine, Nagoya; ${ }^{\mathrm{cc}}$ the Mother and Child Health Institute, Medical Faculty, University of Belgrade; ${ }^{\mathrm{dd}}$ the Department of Pediatrics and Adolescent Medicine, University Medical Center Ulm; ${ }^{\text {ee }}$ the Michael Cuccione Childhood Cancer Research Program, BC Children's Hospital and Child and Family Research Institute, Vancouver; ${ }^{\mathrm{ff}}$ the Department of Oncology, Children's Hospital at Westmead; ${ }^{\mathrm{gg}}$ the Primary Immunodeficiency Group, Institute of Cellular Medicine, Newcastle University, Newcastle upon Tyne; ${ }^{\text {hh }}$ the Department of Pediatric Hematology Oncology, Hannover Medical; ${ }^{\mathrm{jj}}$ the Department of Pediatric Hematology, Oncology and Stem Cell Transplantation, Helsinki University Hospital; ${ }^{\mathrm{k}}$ Paediatric Haematology \& Oncology, Kinderklinik der Technische Universität München, Krankenhaus München-Schwabing, Munich; "lthe Department of Immunology, Children's Memorial Health Institute, Warsaw;

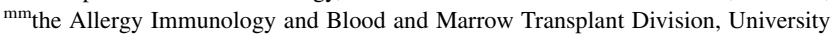
of California San Francisco Benioff Children's Hospital; ${ }^{\mathrm{nn}}$ the Department of Systems Medicine, University of Rome "Tor Vergata", Unit of Immune and Infectious Diseases, Children's Hospital Bambino Gesù, Rome; and ${ }^{\circ}$ Duke University School of Medicine, Pediatric Blood and Marrow Transplant Program, Duke University Medical Center, Durham. 
multiple indications, and 6 had no information. Twenty-two received MAC, 59 received RIC, and 4 were infused; information was unavailable for 2 patients. Seventy-three of 77 patients with DNA ligase IV deficiency, Cernunnos-XLF deficiency, or Nijmegen breakage syndrome received conditioning. Survival was $53(69 \%)$ of 77 and was worse for those receiving MAC than for those receiving RIC $(P=.006)$. Most deaths occurred early after transplantation, suggesting poor tolerance of conditioning. Survival in patients with AT was $25 \%$. Forty-one $(49 \%)$ of 83 patients experienced acute GvHD, which was less frequent in those receiving RIC compared with those receiving MAC (26/56 [46\%] vs 12/21 [57\%], $P=.45)$. Median follow-up was 35 months (range, 2-168 months). No secondary malignancies were reported during 15 years of follow-up. Growth and developmental delay remained after HCT; immune-mediated complications resolved.

Conclusion: RIC HCT resolves DNA repair disorder-associated immunodeficiency. Long-term follow-up is required for secondary malignancy surveillance. Routine HCT for AT is not recommended. (J Allergy Clin Immunol 2018;141:322-8.)

Key words: Ataxia-telangiectasia, Cernunnos-XLF deficiency, DNA repair disorders, DNA ligase IV deficiency, hematopoietic stem cell transplantation, Nijmegen breakage syndrome

Maintenance of genomic stability requires repair of DNA that was damaged through endogenous processes, such as meiotic and mitotic replication errors, and exogenous processes, including exposure to oxidizing radicals, DNA-damaging chemicals, and UV and ionizing radiation. Several repair pathways regulate the cell cycle and recognize and repair DNA damage. One of the most serious events to threaten genomic stability, DNA double-strand breaks (DNA-dsbs), if left unchecked will lead to loss of genomic material, mutagenesis, and oncogenesis or cell death. ${ }^{1}$ Two pathways are used to repair such damage: homologous recombination, which functions primarily in dividing cells and the $S$ phase and requires a homologous template to maintain replication accuracy, and non-template-dependent nonhomologous end-joining (NHEJ), which is used particularly during phases of the cell cycle

M.J.C. was supported by the Division of Allergy, Immunology, and Transplantation; the National Institute of Allergy and Infectious Diseases; the Intramural Research Program of the National Institute of Allergy and Infectious Diseases; and the Office of Rare Diseases Research, National Center for Advancing Translational Sciences, National Institutes of Health (U54-AI082973). M.E. was funded in part by Public Health Service grant U24-CA76518 from the National Cancer Institute; the National Heart, Lung, and Blood Institute; and the National Institute of Allergy and Infectious Diseases. L.I.G.-G. was supported by a grant from Fondo de Investigación Sanitaria (FIS-PI16/2053). H.B.G. is supported by the Great Ormond Street Hospital Children's Charity and by the National Institute of Health Research Biomedical Research Centre at Great Ormond Street Hospital and University College London.

Disclosure of potential conflict of interest: M. H. Albert has personally received money for expert testimony from Biotest; grants from GlaxoSmithKline for other works; payment for lectures from Jazz; stock options from Amgen, BMS, and Biotest; and travel expenses from Neovii. R. H. Buckley's institution has received grant money from the Primary Immune Deficiency Treatment Consortium (PIDTC) for other works, is personally a board member of the Immune Deficiency Foundation, is employed by Duke University, has received royalties from UpToDate, and received travel expenses from the National Institutes of Health (NIH) and IDF. H. B. Gaspar has personally received board membership consultancy fees and stock options from Orchard Therapeutics. L. I. Gonzalez-Granado's institution has received grant FIS-PI16/2053 from Fonde de Investiagción Sanitaiia. T. Güngör has personally received board membership from the CGD Society UK and consultancy fees from Novartis. K. Imai's institution has received a grant from the Japanese Ministry of Health, Labor and
Abbreviations used

aGvHD: Acute graft-versus-host disease

AT: Ataxia-telangiectasia

ATG: Anti-thymocyte globulin

ATM: Ataxia-telangiectasia mutated

cGvHD: Chronic graft-versus-host disease

Cernunnos-XLF: Cernunnos-XRCC4-like factor

DNA-dsb: DNA double-strand break

GvHD: Graft-versus-host disease

HCT: Hematopoietic cell transplantation

LIG4: DNA ligase IV deficiency

MAC: Myeloablative conditioning

NBS: Nijmegen breakage syndrome

NHEJ: Nonhomologous end-joining

NHEJ1: Nonhomologous end-joining factor 1

NK: Natural killer

PTLD: Posttransplantation lymphoproliferative disorder

RAG: Recombination-activating gene

RIC: Reduced-intensity conditioning

SCID: Severe combined immunodeficiency

when a homologous template is not present. The latter is an especially error-prone process, with some loss of DNA information at the site of the DNA-dsb. ${ }^{2}$

Development of normal adaptive immunity requires generation of a wide range of $\mathrm{T}$ - and $\mathrm{B}$-lymphocyte receptors to recognize unique antigen/MHC combinations and provides effective defense against a broad repertoire of pathogens. Many genetically diverse receptors are generated in the thymus and bone marrow by breaking, stochastically rearranging, and rejoining DNA sequences coding for antigen receptors, a process known as VDJ recombination. Additional diversity is created in B lymphocytes during immunoglobulin class-switch recombination and somatic hypermutation. The DNA repair mechanisms required to maintain somatic genomic stability are also used during lymphocyte VDJ recombination to repair intermediate DNA hairpins and physiologic DNA-dsbs created after activation of recombination-activating gene (RAG) 1

Welfare for work outside this manuscript; has personally received consultancy fees from CSL Behring KK and Novartis pharma KK; and has received payment for lectures from CSL Behring KK and Novartis pharma KK. R. Meisel has received consultancy fees from Amgen and has received travel expenses from Neovii Biotech and Jazz Pharmaceuticals. A. Schulz's institution has received travel expenses from the European Society for Blood and Marrow Transplantation. M. J. Cowan's institution has received grant U54 AI 082973 from the NIH for this work and grants U54AI082973, CLIN1-08363, and CLIN2-09504 from the California Institute of Regenerative Medicine for other works and has personally received board membership from Bluebird Bio, royalties from UpToDate, and stock options from Homology Medicines and Exogen Bio. The rest of the authors declare that they have no relevant conflicts of interest.

Received for publication November 2, 2016; revised January 25, 2017; accepted for publication February 6, 2017.

Available online April 7, 2017.

Corresponding author: Andrew R. Gennery, MD, Clinical Resource Building, Floor 4, Block 2 Great North Children's Hospital, Queen Victoria Road, Newcastle upon Tyne NE1 4LP, United Kingdom. E-mail: a.r.gennery@ncl.ac.uk.

Q The CrossMark symbol notifies online readers when updates have been made to the article such as errata or minor corrections

0091-6749/\$36.00

(C) 2017 American Academy of Allergy, Asthma \& Immunology

http://dx.doi.org/10.1016/j.jaci.2017.02.036 
and $2 .{ }^{3}$ Seven ubiquitously expressed proteins are associated with NHEJ-Ku70/80 and DNA protein kinase catalytic subunit, which stabilize the DNA break; the DNA endo/exonuclease Artemis, which is important for processing RAG-induced hairpin intermediate joins; and the DNA ligase IV and Cernunnos-XRCC4-like factor (Cernunnos-XLF), which together are responsible for the ligation step. Additionally, ataxia-telangiectasia mutated (ATM) and nibrin proteins are involved in the initial cell-cycle arrest and recruitment of NHEJ proteins to the breakage site (see Fig E1 in this article's Online Repository at www.jacionline.org). ${ }^{4}$

Defects in the lymphoid-specific RAG1/2 proteins lead to $\mathrm{T}$ lymphocyte-negative, B lymphocyte-negative, natural killer (NK) lymphocyte-positive $\left(\mathrm{T}^{-} \mathrm{B}^{-} \mathrm{NK}^{+}\right)$severe combined immunodeficiency (SCID). ${ }^{5}$ Defects in Artemis, DNA protein kinase catalytic subunit, DNA ligase IV, and Cernunnos-XLF proteins also lead to $\mathrm{T}^{-} \mathrm{B}^{-} \mathrm{NK}^{+}$SCID and combined immunodeficiencies, often associated with other developmental anomalies, particularly microcephaly in patients with DNA ligase IV and Cernunnos-XLF deficiency, as a result of the ubiquitous expression of these proteins..$^{6-14}$ Hematopoietic cell transplantation (HCT) is curative for $\mathrm{T}^{-} \mathrm{B}^{-} \mathrm{NK}^{+} \mathrm{SCID}$, but best results with donor myeloid chimerism and long-term immune reconstitution are obtained if preparative chemotherapy is administered before transplantation. ${ }^{15}$ However, in Artemis-deficient radiosensitive patients with SCID, although overall survival is equivalent to that of patients with RAG-deficient SCID, significant long-term sequelae result from administration of alkylating agents, which are required to gain donor stem cell engraftment with sustained long-term thymopoiesis. The use of alkylating chemotherapy does not result in increased short-term toxicities or increased transplant-related mortality, but long-term effects on growth and development are observed because of the effect of chemotherapy on other somatic cells that harbor the genetic defect. ${ }^{15}$ Similar significant effects of chemotherapy are seen in patients with Fanconi anemia (OMIM 227650) and dyskeratosis congenita (OMIM 127550), both of which are DNA fragility syndromes. ${ }^{16,17}$ Given the systemic nature of the DNA-dsb defect in other DNA-dsb repair disorders and the finding that the radiosensitivity is generally more severe than in patients with Artemis deficiency, it is possible that preadministration of DNA-damaging chemotherapy before transplantation will lead to significant systemic morbidity and possible increased mortality.

Because of the primary immunodeficiency phenotype and the frequent occurrence of malignancy, a number of patients with DNA-dsb repair disorders have undergone HCT. ${ }^{10-13,18-28}$ To assess outcomes of HCT for DNA-dsb repair disorders, we surveyed patients undergoing transplantation for DNA ligase IV deficiency (LIG4), Cernunnos-XLF deficiency (XLF; or nonhomologous end-joining factor 1 [NHEJ1]), Nijmegen breakage syndrome (NBS), and ataxia-telangiectasia (AT) using baseline data from Stem Cell Transplant for Primary Immune Deficiencies in Europe, the Inborn Errors Working Party of the European Society for Blood and Marrow Transplantation registry, the Center for International Blood and Marrow Transplant Research, and the North American Primary Immune Deficiency Treatment Consortium and supplemented with additional information from individual centers, where available. Patients with mutations in RAG1/2 and DCLREIC (encoding Artemis) were excluded from the study because HCT outcomes for these conditions have been reported recently. ${ }^{15}$

\section{METHODS}

\section{Data collection}

Data on patients with defined mutations in LIG4 (OMIM 606593), NBN (OMIM 602667), NHEJ1 (OMIM 611290), and ATM (OMIM 607585) who underwent HCT were gathered from the Inborn Errors Working Party of European Society for Blood and Marrow Transplantation, Stem Cell Transplant for primary Immune Deficiencies in Europe, the Center for International Blood and Marrow Transplant Research, and the North American Primary Immunodeficiency Treatment Consortium. Further patients were identified from previously published data and case reports. Centers with identified patients completed a questionnaire to gather data on genetic diagnosis, patients' demographics, reason for HCT, type and source of HCT, conditioning regimen used, rates and severity of graft-versus-host disease (GvHD), and survival after HCT. Inclusion criteria were any patient having a confirmed genetic diagnosis and having undergone HCT.

The reason to offer HCT was defined as any category or combination of the following:

- infection (defined as any listed severe infection or recurrent infections);

- malignancy;

- bone marrow failure (defined as leukopenia, anemia, or thrombocytopenia without the presence of infection or malignancy);

- autoimmunity; and

- pre-emptive.

Conditioning was categorized as either MAC or RIC. MAC was defined as any regimen using high-dose alkylating agents, typically melphalan or busulphan, thiotepa, or total-body irradiation at any dose. Although a lowdose 200- to 400-cGy regimen can normally be considered nonmyeloablative, we reasoned that radiation-sensitive cells were best not exposed to ionizing radiation. If the regimen did not use alkylating agents and/or had doses of fludarabine of $150 \mathrm{mg} / \mathrm{m}^{2}$ or less and cyclophosphamide of $40 \mathrm{mg} / \mathrm{kg}$ or less, it was defined as RIC. ${ }^{29}$ A modified Fanconi regimen was based on 120 to $150 \mathrm{mg} / \mathrm{m}^{2}$ fludarabine ( $30 \mathrm{mg} / \mathrm{m}^{2} / \mathrm{d}$ in $4-5$ divided doses), 20 to $40 \mathrm{mg} / \mathrm{kg}$ cyclophosphamide (in 4 divided doses) with or without anti-thymocyte globulin (ATG) or alemtuzumab serotherapy, ${ }^{30,31}$ or $180 / \mathrm{m}^{2}$ fludarabine (in 6 divided doses), $1.6 \mathrm{mg} / \mathrm{kg}$ busulphan (in 2 divided doses), and $40 \mathrm{mg} / \mathrm{kg}$ cyclophosphamide (in 2 divided doses). ${ }^{32}$ The use of targeted agents, such as antibodies (eg, alemtuzumab) did not affect classification of the conditioning.

The primary outcome measured was survival. Secondary outcome measures sought were presence, severity, and outcome of GvHD, or other transplant-related complications.

\section{Analysis}

Significance of results was determined by using the Fisher exact test with $2 \times 2$ contingency tables. A 2-tailed $P$ value of .05 or less was considered significant. Kaplan-Meier curves were created based on last known status at the time at which the questionnaire was received; cases in which survival was not listed have been excluded from the survival analysis. All statistics were calculated with GraphPad Prism 6 software (GraphPad Software, La Jolla, Calif).

\section{RESULTS}

Data were collected from 38 centers worldwide, culminating in 55 newly identified patients and 14 previously published patients with updated new information, producing new information on 69 patients. Available data from 18 previously published cases $^{10-14,18-28}$ were included, where possible, totaling 87 cases. The median age of patients at HCT was 48 months (range, 1.5-552 months), and 47 were male (54\%).

Mutations in LIG4 were most commonly represented in 36 patients (32 unpublished or with new information, see Table E1 in this article's Online Repository at www.jacionline.org), 26 with $N B N$ mutations (17 unpublished or with new information, see Table E2 in this article's Online Repository at www.jacionline.org), 17 with NHEJ1 mutations (12 unpublished 


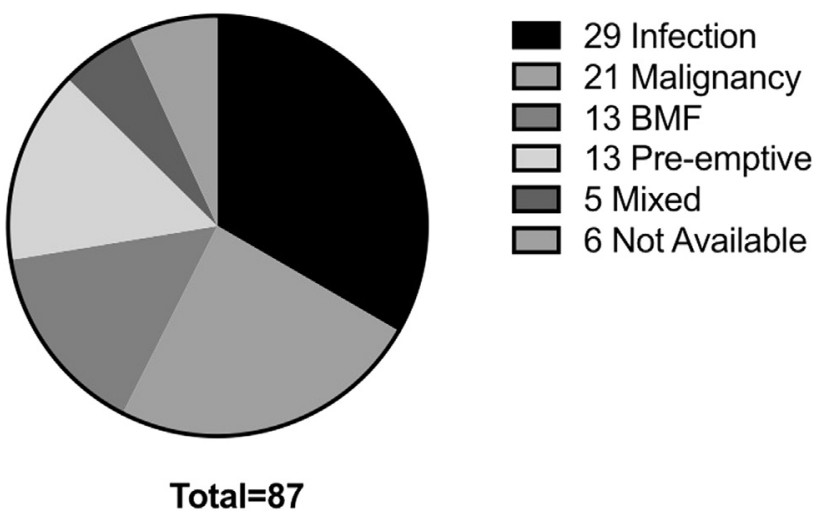

FIG 1. Indication for HCT. BMF, Bone marrow failure.

or with new information, see Table E3 in this article's Online Repository at www.jacionline.org), and 8 with ATM mutations (all with new information, 2 previously published, updated in this report; see Table E4 in this article's Online Repository at www.jacionline.org). All patients received allogeneic hematopoietic stem cells, except 2 published patients who died immediately before HCT while receiving MAC but whose data were included in the study.

Information was provided on the primary reason for HCT in 83 patients (Fig 1). Significant or repeated infections were the most commonly cited reason (29 [35\%] patients, 12 with LIG4 mutations and 11 with NHEJ1 mutations), 13 (15\%) patients underwent transplantation for bone marrow failure, and 21 (24\%) patients underwent transplantation for malignancy (17 with NBN mutations). Thirteen (15\%) patients underwent transplantation pre-emptively on the basis of an SCID-like diagnosis, 10 with LIG4 mutations. Five patients had a mixture of the above indications, and in 6 patients the reason for HCT was not available.

Twenty-two patients received MAC, and 59 received RIC, of which 30 were based on a modified Fanconi anemia conditioning regimen. Four patients received a stem cell infusion without prior conditioning; data were unavailable for 2 patients. Two received radiotherapy ( 5 and $2 \mathrm{~Gy}$, respectively) as part of the conditioning regimen.

\section{Survival}

Of patients with LIG4, Cernunnos-XLF deficiency, and NBS, there were survival data for 77 , of whom 73 received conditioning. Overall survival was 53 (69\%) of 77 (Fig 2, A), 2 of whom died from relapse of malignancy, resulting in a transplant-related survival of $71 \%$. One patient with NBS rejected the graft and is alive with disease. One rejected and succumbed to malignancy. Survival among those receiving MAC was significantly worse at $41 \%$ (7/17) compared with 79\% (44/56) for those receiving RIC $(P=.006 ;$ Fig $2, B)$, describing 2 patients who died of malignancy relapse as survivors. There was no significant difference in transplant-related mortality between those who received a modified Fanconi or other RIC regimen $(P=.13)$. The KaplanMeier curve demonstrates that the majority of deaths occur early in the course of transplantation, particularly in those receiving MAC, suggesting poor tolerance of the conditioning regimen.

In patients with AT, overall survival was $25 \%$. Of the 2 patients who survived, both received a modified Fanconi conditioning

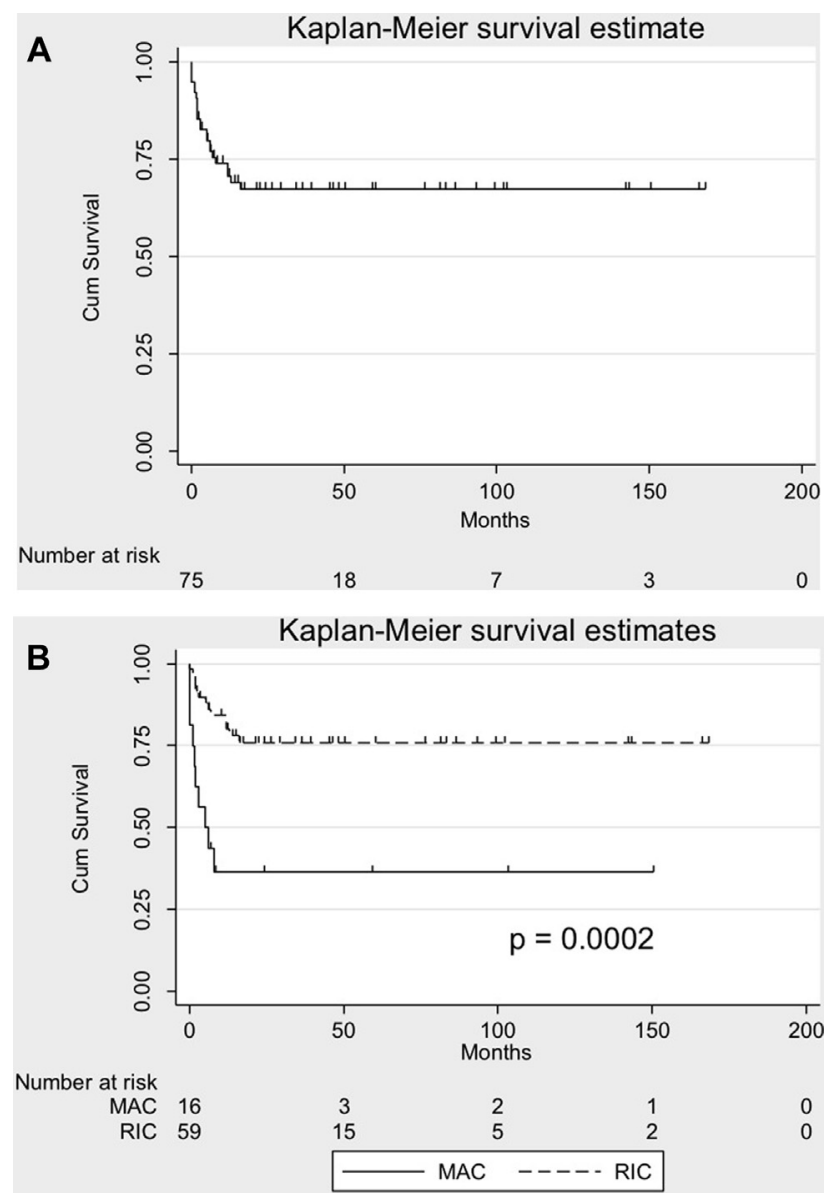

FIG 2. Probabilities of overall survival. A, Kaplan-Meier curve showing overall survival of 74 patients with LIG4, Cernunnos-XLF deficiency, and NBS. B, Kaplan-Meier curve demonstrating differences in survival of 74 patients with LIG4, Cernunnos-XLF deficiency, and NBS undergoing transplantation with RIC or MAC regimens.

regimen, and neither experienced GvHD, unlike all patients who received MAC. The 6 patients who died experienced GvHD grade 2 or $3(67 \%)$, despite well-matched donors. Death was due to multiorgan failure, viral activation, or posttransplantation lymphoproliferative disorder (PTLD).

Transplant-related survival in the entire cohort for whom data were available was $66 \%(56 / 85)$, with a survival of $75 \%(45 / 60)$ after RIC and $32 \%(7 / 22)$ after MAC $(P=.0006)$. There was no significant difference in outcome between those who underwent HCT for malignancy (12/22 survivors) or for other indications (37/57 survivors, $P=.44$ ). There was no significant difference in survivors for those receiving RIC (11/17) or MAC (1/5) conditioning when malignancy was the reason for HSCT $(P=.14)$. There was also no significant difference in survivors for those receiving RIC $(5 / 25)$ or MAC (4/9) when infection was the reason for HSCT $(P=.09)$. There were too few patients who underwent transplantation for bone marrow failure to make a similar comparison.

There were no differences in survival between donor sources, irrespective of whether matched sibling, matched unrelated, or mismatched unrelated donors were used $(18 / 25,20 / 27$, and 5/8, respectively). 


\section{GvHD}

Data on the presence or absence of acute graft-versus-host disease (aGvHD) was available for 83 patients; aGvHD was present in $41(49 \%)$ of these. Of the reported patients with aGvHD, 24 (59\%) had mild (grade 1-2) and 15 (37\%) had severe (grade 3-4) aGvHD (a grade was unavailable for 2 patients). Rates of aGvHD were lower in the RIC group, 26 (46\%) of 56 cases for whom data were available, compared with the MAC group, in whom $12(57 \%)$ of 21 cases experienced aGvHD, although this was not statistically significant $(P=.45)$. Three of 4 patients who received infused stem cells with no preconditioning experienced grade 1, 3, and 4 aGvHD respectively. There was no significant difference in survival between those experiencing grade 0 or 1 compared with those receiving grade 2 to $4 \mathrm{aGvHD}(P=.22)$.

\section{Mortality}

Overall mortality was $29(34 \%)$ of 84 ; information was unavailable for 2 previously published patients. ${ }^{24}$ Two patients died of multiorgan failure during the conditioning process; both received full MAC. Eleven others died of multiorgan failure after transplantation, making multiorgan failure the most common cause of death $(45 \%)$. Eleven deaths were predominantly infectious $(38 \%)$.

\section{Other complications}

The most common non-aGvHD complication was viremia caused by adenovirus, cytomegalovirus, EBV, or a combination, which was reported in 24 (30\%) of 79 patients, 6 of whom died. There were $6(8 \%)$ cases of EBV-related PTLD. Six (8\%) patients experienced severe mucositis, and $14(18 \%)$ had chronic graft-versus-host disease (cGvHD). Seven patients rejected the graft: 2 after stem cell infusion (1 with serotherapy), 2 after T lymphocyte-depleted transplantations (1 MAC and 1 RIC), and 3 after MAC or RIC transplantations. Patients receiving RIC were less likely to experience severe mucositis, veno-occlusive disease, or PTLD than those who received MAC (7/59 vs 8/22, $P=.0215)$.

\section{Follow-up}

Given the retrospective and multi-institutional nature of the study, detailed information regarding long-term ( $>5$ years) follow-up was scarce. Median length of follow-up was 35 months (range, 2-168 months). No secondary malignancies were reported during the follow-up period, which, although short overall, includes patients with almost 15 years of follow-up. Pre-existing growth restriction and developmental issues appear to remain after HCT: a more detailed examination would be required to determine whether HCT ameliorates these features. A predisposition to infection or hematologic cytopenia existing before HCT appears to have been abolished.

\section{DISCUSSION}

Many patients with DNA-dsb repair defects exhibit immunodeficiency, ranging from mild to severe combined immunodeficiency, and are at increased risk of lymphoid malignancy. Allogeneic HCT is curative for many immunodeficiencies. ${ }^{33}$ Establishment of effective DNA repair mechanisms in lymphoid progenitors leading to restoration of functional adaptive immunity might prevent the future development of lymphoid malignancy in this cohort of patients. Lymphoid malignancy is difficult to treat effectively when established because of the aggressive nature of the tumors and poor tolerance of patients to cytotoxic radiotherapy and chemotherapy. ${ }^{34}$ Therefore it is a reasonable strategy to consider HCT in these patients. However, because most patients have some residual immunity and NK cells are present even in the SCID phenotype, rejection and poor stem cell engraftment are likely without some preparative cytoreductive preconditioning. However, the systemic nature of the genetic defect increases the risk of substantial morbidity or mortality from chemotherapy or ionizing radiation administered before transplantation. Only a few small case series of patients with DNA-dsb repair defects undergoing HCT have been published. To date, there has been no formal large case series from which to gauge experience.

We now report a multi-institutional retrospective survey on outcomes of HCT for 55 previously unpublished patients and update information for 18 previously reported patients with DNA-dsb repair defects. We have demonstrated that HCT can correct the hematopoietic defect and underlying immunodeficiency. Furthermore, we have demonstrated that survival is significantly superior when RIC is used. It is likely that chemotherapy agents, especially alkylating agents, induce systemic double-strand breaks, which are not readily repaired because of the underlying genetic defect. These systemic double-strand breaks can contribute to the early mortality seen after myeloablative therapy. This intolerance, which manifests clinically as severe toxicity sometimes followed by higher-grade GvHD, suggests that when considering HCT, an RIC regimen should be used in patients with known ionizing radiation sensitivity and/or proved diagnosis of a DNA-dsb repair defect and that radiotherapy should be omitted. Given the equivalence of outcome results when comparing modified Fanconi anemiabased regimens with other reduced-intensity regimens, the former might be preferred. Longer-term follow-up is required to determine the effect of HCT on future prevention of lymphoid malignancy.

The rate of aGvHD overall was $49 \%$, of which $37 \%$ was grade 3 or 4 . The rate of cGvHD was $18 \%$. The incidence of severe (grade 3-4) aGvHD and cGvHD is higher than that reported for transplantation of patients with other primary immunodeficiencies. $^{35-38}$ It is not clear whether this is due to the greater use of matched unrelated donors rather than matched sibling donors (although in the modern era outcome of HCT with matched siblings or unrelated donors approaches equivalence), particularly in those receiving RIC. Significant comorbidities might also have contributed to the increased incidence of GvHD. However, it could be that the underlying molecular defect causing impaired DNA repair and reduced cellular repair capability predisposes to GvHD after cellular damage, as found in patients with Fanconi anemia or dyskeratosis congenita. ${ }^{17,39}$

Patients showed a range of other early post-HCT complications in addition to GvHD. Most common were viral reactivations, which in the case of EBV led to PTLD in 6 patients. Severe mucositis and veno-occlusive disease were commonly encountered.

Three patients experienced veno-occlusive disease, and 2 who underwent transplantation for malignancy experienced relapse of the primary malignancy. Three patients had autoimmune thyroid disease, and autoimmune cytopenias were also manifest. 
Within this patient cohort, there are few data on long-term follow-up. Transplantation, unsurprisingly given the systemic nature of the defect, appears not to improve the effects of the primary disease on growth or neurologic development. It might be, as in patients with Artemis-SCID, that use of any alkylating agent leads to long-term sequalae. ${ }^{15}$ It will be difficult to predict whether growth or development has been improved or deteriorated as a result of chemotherapy given the scarce data available on the natural history of these diseases and the variability of the phenotype already reported. However, determining the long-term and late beneficial and adverse effects of HCT in DNA-dsb defects will be important to provide details about the utility of this treatment approach. A recent report on a cohort of patients with mutations in $N B N$ documented poor survival in those with malignancy. ${ }^{24}$ Given the good survival outcome in this cohort among those who received RIC regimens, a pre-emptive approach to transplantation can be considered. Therefore long-term follow-up to determine the frequency of secondary malignancies will be of particular importance; although it has not been reported thus far in other primary immunodeficiency transplant series, it is a well-recognized complication in patients undergoing transplantation for Fanconi anemia. $^{39}$

Although the outcome of HCT in patients with mutations in $L I G 4, N B N$, and NHEJ1 is favorable, particularly when RIC regimens are used, the data for patients with AT undergoing HCT are disappointing. Whether this is specifically due to the use of MAC regimens or the presence of malignancy, precipitating transplantation as a therapeutic option is not clear. With current results, it is difficult to recommend HCT as a treatment option for patients with AT, except in clinical trials. In contrast, patients with the other conditions described have transplantation outcomes similar to those with other primary immunodeficiencies when choosing RIC. Therefore transplantation could be considered more favorably as a pre-emptive therapeutic approach, particularly if radiotherapy is omitted from the conditioning regimen and low-intensity conditioning regimens are used. However, the high rate of posttransplantation complications, including GvHD, remains a concern and should drive the development of alternative low or nontoxic conditioning approaches that relieve these patients of the deleterious effects of alkylating therapy but enable full $\mathrm{T}$ - and B-lymphocyte reconstitution. In the meantime, careful follow-up is required to observe further systemic benefits from transplantation, if any, and importantly to monitor for long-term adverse events. In the future, gene therapy might be an acceptable alternative treatment strategy for this group of patients.

\section{Clinical implications: HCT cures DNA breakage repair disor- ders. Patients with Cernunnos-XLF deficiency, LIG4, and NBS receiving alkylator or radiotherapy preconditioning have worse survival than those receiving RIC.}

\section{REFERENCES}

1. Wang C, Lees-Miller SP. Detection and repair of ionizing radiation-induced DNA double strand breaks: new developments in nonhomologous end joining. Int J Radiat Oncol Biol Phys 2013;86:440-9.

2. Waters CA, Strande NT, Wyatt DW, Pryor JM, Ramsden DA. Nonhomologous end joining: a good solution for bad ends. DNA Repair (Amst) 2014;17:39-51.

3. Goodarzi AA, Jeggo PA. The repair and signaling responses to DNA double-strand breaks. Adv Genet 2013;82:1-45.
4. Woodbine L, Gennery AR, Jeggo PA. The clinical impact of deficiency in DNA non-homologous end-joining. DNA Repair (Amst) 2014;17:9-20.

5. Schwarz K, Gauss GH, Ludwig L, Pannicke U, Li Z, Lindner D, et al. RAG mutations in human B cell-negative SCID. Science 1996;274:97-9.

6. Moshous D, Callebaut I, de Chasseval R, Corneo B, Cavazzana-Calvo M, Le Deist F, et al. Artemis, a novel DNA double-strand break repair/V(D)J recombination protein, is mutated in human severe combined immune deficiency. Cell 2001;105:177-86.

7. Moshous D, Pannetier C, de Chasseval R, le Deist F, Cavazzana-Calvo M, Romana $\mathrm{S}$, et al. Partial $\mathrm{T}$ and $\mathrm{B}$ lymphocyte immunodeficiency and predisposition to lymphoma in patients with hypomorphic mutations in Artemis. J Clin Invest 2003;111:381-7.

8. van der Burg M, Ijspeert H, Verkaik NS, Turul T, Wiegant WW, Morotomi-Yano $\mathrm{K}$, et al. A DNA-PKes mutation in a radiosensitive T-B- SCID patient inhibits Artemis activation and nonhomologous end-joining. J Clin Invest 2009;119:91-8.

9. Woodbine L, Neal JA, Sasi NK, Shimada M, Deem K, Coleman H, et al. PRKDC mutations in a SCID patient with profound neurological abnormalities. J Clin Invest 2013;123:2969-80.

10. O'Driscoll M, Cerosaletti KM, Girard PM, Dai Y, Stumm M, Kysela B, et al. DNA ligase IV mutations identified in patients exhibiting developmental delay and immunodeficiency. Mol Cell 2001;8:1175-85.

11. Buck D, Moshous D, de Chasseval R, Ma Y, le Deist F, Cavazzana-Calvo M, et al. Severe combined immunodeficiency and microcephaly in siblings with hypomorphic mutations in DNA ligase IV. Eur J Immunol 2006;36:224-35.

12. Enders A, Fisch P, Schwarz K, Duffner U, Pannicke U, Nikolopoulos E, et al. A severe form of human combined immunodeficiency due to mutations in DNA ligase IV. J Immunol 2006;176:5060-8.

13. van der Burg M, van Veelen LR, Verkaik NS, Wiegant WW, Hartwig NG, Barendregt $\mathrm{BH}$, et al. A new type of radiosensitive T-B-NK + severe combined immunodeficiency caused by a LIG4 mutation. J Clin Invest 2006;116:137-45.

14. Buck D, Malivert L, de Chasseval R, Barraud A, Fondanèche MC, Sanal O, et al. Cernunnos, a novel nonhomologous end-joining factor, is mutated in human immunodeficiency with microcephaly. Cell 2006;124:287-99.

15. Schuetz C, Neven B, Dvorak CC, Leroy S, Ege MJ, Pannicke U, et al. SCID patients with ARTEMIS vs RAG deficiencies following HCT: increased risk of late toxicity in ARTEMIS-deficient SCID. Blood 2014;123:281-9.

16. Deeg HJ, Socié G, Schoch G, Henry-Amar M, Witherspoon RP, Devergie A, et al. Malignancies after marrow transplantation for aplastic anemia and Fanconi anemia: a joint Seattle and Paris analysis of results in 700 patients. Blood 1996; $87: 386-92$.

17. Gadalla SM, Sales-Bonfim C, Carreras J, Alter BP, Antin JH, Ayas M, et al. Outcomes of allogeneic hematopoietic cell transplantation in patients with dyskeratosis congenita. Biol Blood Marrow Transplant 2013;19:1238-43.

18. Gruhn B, Seidel J, Zintl F, Varon R, Tönnies H, Neitzel H, et al. Successful bone marrow transplantation in a patient with DNA ligase IV deficiency and bone marrow failure. Orphanet J Rare Dis 2007;2:5.

19. Grunebaum E, Bates A, Roifman CM. Omenn syndrome is associated with mutations in DNA ligase IV. J Allergy Clin Immunol 2008;122:1219-20.

20. Straathof KC, Rao K, Eyrich M, Hale G, Bird P, Berrie E, et al. Haemopoietic stem cell transplantation with antibody-based minimal intensity conditioning. Lancet 2009;374:912-20.

21. Albert MH, Gennery AR, Greil J, Cale CM, Kalwak K, Kondratenko I, et al. Successful Stem cell transplantation for Nijmegen breakage syndrome. Bone Marrow Transplant 2010;45:622-6.

22. Woźniak M, Krzywoń M, Hołda MK, Goździk J. Reduced-intensity conditioning umbilical cord blood transplantation in Nijmegen breakage syndrome. Pediatr Transplant 2015;19:E51-5.

23. Stajner T, Vasiljević Z, Vujić D, Marković M, Ristić G, Mićić D, et al. Atypical strain of Toxoplasma gondii causing fatal reactivation after hematopoietic stem cell transplantation in a patient with an underlying immunological deficiency. J Clin Microbiol 2013;51:2686-90.

24. Dai Y, Kysela B, Hanakahi LA, Manolis K, Riballo E, Stumm M, et al. Nonhomologous end joining and V(D)J recombination require an additional factor: Proc Natl Acad Sci U S A 2003;100:2462-7.

25. Faraci M, Lanino E, Micalizzi C, Morreale G, Di Martino D, Banov L, et al. Unrelated hematopoietic stem cell transplantation for Cernunnos-XLF deficiency. Pediatr Transplant 2009;13:785-9.

26. Çă̆daș D, Özgür TT, Asal GT, Revy P, De Villartay JP, van der Burg M, et al. Two SCID cases with Cernunnos-XLF deficiency successfully treated by hematopoietic stem cell transplantation. Pediatr Transplant 2012;16:E167-71.

27. Ghosh S, Schuster FR, Binder V, Niehues T, Baldus SE, Seiffert P, et al. Fatal outcome despite full lympho-hematopoietic reconstitution after allogeneic stem cell transplantation in atypical ataxia telangiectasia. J Clin Immunol 2012;32: 438-40. 
28. Ussowicz M, Musiał J, Duszeńko E, Haus O, Kałwak K. Long-term survival afte allogeneic-matched sibling PBSC transplantation with conditioning consisting of low-dose busilvex and fludarabine in a 3-year-old boy with ataxia-telangiectasia syndrome and ALL. Bone Marrow Transplant 2013;48:740-1.

29. Bacigalupo A, Ballen K, Rizzo D, Giralt S, Lazarus H, Ho V, et al. Defining the intensity of conditioning regimens: working definitions. Biol Blood Marrow Transplant 2009;15:1628-33.

30. de la Fuente J, Reiss S, McCloy M, Vulliamy T, Roberts IA, Rahemtulla A, et al Non-TBI stem cell transplantation protocol for Fanconi anaemia using HLA-compatible sibling and unrelated donors. Bone Marrow Transplant 2003; 32:653-6.

31. Available at: https://www.ebmt.org/Contents/About-EBMT/Who-We-Are/Scientific Council/Documents/EBMT_ESIDGUIDELINESFORINBORNERRORSFINAL 2011.pdf. Accessed October 16, 2016.

32. Chao MM, Ebell W, Bader P, Beier R, Burkhardt B, Feuchtinger T, et al. Consensus of German transplant centers on hematopoietic stem cell transplantation in Fanconi anemia. Klin Padiatr 2015;227:157-65.

33. Gennery AR, Slatter MA, Grandin L, Taupin P, Cant AJ, Veys P, et al Transplantation of haematopoietic stem cells and long term survival for primary immunodeficiencies in Europe: entering a new century, do we do better? J Allergy Clin Immunol 2010;26:602-10, e1-11.
34. Wolska-Kusnierz B, Gregorek H, Chrzanowska K, Piątosa B, Pietrucha B, Heropolitańska-Pliszka E, et al. Nijmegen breakage syndrome: clinical and immunological features, long-term outcome and treatment options. J Clin Immunol 2015;35:538-49.

35. Güngör T, Albert MH, Teira P, Slatter M, Stüssi G, Stepensky P, et al. Reducedintensity conditioning and HLA-matched haemopoietic stem-cell transplantation in patients with chronic granulomatous disease: a prospective multicentre study. Lancet 2014;838:436-48.

36. Booth C, Gilmour KC, Veys P, Gennery AR, Slatter MA, Chapel H, et al. X-linked Lymphoproliferative Disease due to SAP/SH2D1A deficiency: a multicentre study on the manifestations, management and outcome of the disease. Blood 2011;117: 53-62.

37. Mahlaoui N, Pellier I, Mignot C, Jais JP, Bilhou-Nabéra C, Moshous D, et al. Characteristics and outcome of early-onset, severe forms of Wiskott-Aldrich syndrome. Blood 2013;121:1510-6.

38. Ouachee-Chardin M, Elie C, de Saint Basile G, Le Deist F, Mahlaoui N, Picard C, et al. Hematopoietic stem cell transplantation in hemophagocytic lymphohistiocytosis: a single-center report of 48 patients. Pediatrics 2006;117:e743-50.

39. Peffault de Latour R, Porcher R, Dalle JH, Aljurf M, Korthof ET, Svahn J, et al. Allogeneic hematopoietic stem cell transplantation in Fanconi anemia: the European Group for Blood and Marrow Transplantation experience. Blood 2013; $122: 4279-86$. 


\section{REFERENCES}

E1. O'Driscoll M, Cerosaletti KM, Girard PM, Dai Y, Stumm M, Kysela B, et al DNA ligase IV mutations identified in patients exhibiting developmental delay and immunodeficiency. Mol Cell 2001;8:1175-85.

E2. Buck D, Moshous D, de Chasseval R, Ma Y, le Deist F, Cavazzana-Calvo M, et al. Severe combined immunodeficiency and microcephaly in siblings with hypomorphic mutations in DNA ligase IV. Eur J Immunol 2006;36:224-35.

E3. Enders A, Fisch P, Schwarz K, Duffner U, Pannicke U, Nikolopoulos E, et al. A severe form of human combined immunodeficiency due to mutations in DNA ligase IV. J Immunol 2006;176:5060-8.

E4. van der Burg M, van Veelen LR, Verkaik NS, Wiegant WW, Hartwig NG, Barendregt $\mathrm{BH}$, et al. A new type of radiosensitive T-B-NK+ severe combined immunodeficiency caused by a LIG4 mutation. J Clin Invest 2006;116:137-45.

E5. Deeg HJ, Socié G, Schoch G, Henry-Amar M, Witherspoon RP, Devergie A, et al. Malignancies after marrow transplantation for aplastic anemia and Fanconi anemia: a joint Seattle and Paris analysis of results in 700 patients. Blood 1996;87:386-92.

E6. Grunebaum E, Bates A, Roifman CM. Omenn syndrome is associated with mutations in DNA ligase IV. J Allergy Clin Immunol 2008;122:1219-20.

E7. Straathof KC, Rao K, Eyrich M, Hale G, Bird P, Berrie E, et al. Haemopoietic stem cell transplantation with antibody-based minimal intensity conditioning. Lancet 2009;374:912-20.

E8. Tamura S, Higuchi K, Tamaki M, Inoue C, Awazawa R, Mitsuki N, et al. Novel compound heterozygous DNA ligase IV mutations in an adolescent with a slowly-progressing radiosensitive-severe combined immunodeficiency. Clin Immunol 2015;160:255-60.

E9. Albert MH, Gennery AR, Greil J, Cale CM, Kalwak K, Kondratenko I, et al. Successful Stem cell transplantation for Nijmegen breakage syndrome. Bone Marrow Transplant 2010;45:622-6.
E10. Woźniak M, Krzywoń M, Hołda MK, Goździk J. Reduced-intensity conditioning umbilical cord blood transplantation in Nijmegen breakage syndrome. Pediat Transplant 2015;19:E51-5.

E11. Wolska-Kusnierz B, Gregorek H, Chrzanowska K, Piạtosa B, Pietrucha B, Heropolitańska-Pliszka E, et al. Nijmegen breakage syndrome: clinical and immunological features, long-term outcome and treatment options. J Clin Immunol 2015;35:538-49.

E12. Stajner T, Vasiljević Z, Vujić D, Marković M, Ristić G, Mićić D, et al. Atypical strain of Toxoplasma gondii causing fatal reactivation after hematopoietic stem cell transplantation in a patient with an underlying immunological deficiency. J Clin Microbiol 2013;51:2686-90.

E13. Dai Y, Kysela B, Hanakahi LA, Manolis K, Riballo E, Stumm M, et al Nonhomologous end joining and $\mathrm{V}(\mathrm{D}) \mathrm{J}$ recombination require an additiona factor. Proc Natl Acad Sci U S A 2003;100:2462-7.

E14. Faraci M, Lanino E, Micalizzi C, Morreale G, Di Martino D, Banov L, et al Unrelated hematopoietic stem cell transplantation for Cernunnos-XLF deficiency Pediatr Transplant 2009;13:785-9.

E15. Çağdaş D, Özgür TT, Asal GT, Revy P, De Villartay JP, van der Burg M, et al Two SCID cases with Cernunnos-XLF deficiency successfully treated by hematopoietic stem cell transplantation. Pediatr Transplant 2012;16:E167-71.

E16. Ghosh S, Schuster FR, Binder V, Niehues T, Baldus SE, Seiffert P, et al. Fata outcome despite full lympho-hematopoietic reconstitution after allogeneic stem cell transplantation in atypical ataxia telangiectasia. J Clin Immunol 2012;32: 438-40.

E17. Ussowicz M, Musiał J, Duszeńko E, Haus O, Kałwak K. Long-term survival after allogeneic-matched sibling PBSC transplantation with conditioning consisting of low-dose busilvex and fludarabine in a 3-year-old boy with ataxia-telangiectasia syndrome and ALL. Bone Marrow Transplant 2013;48:740-1. 


\section{A}

$\infty 000000000000000000000000000000000000000000000000$

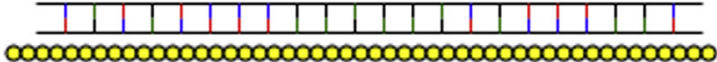

B

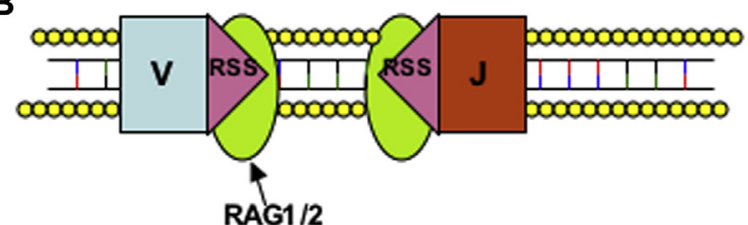

C
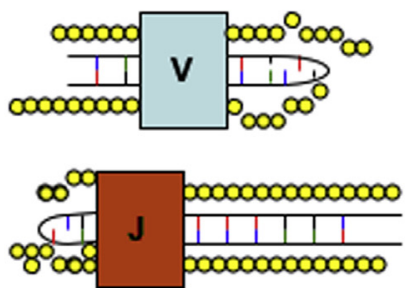

D

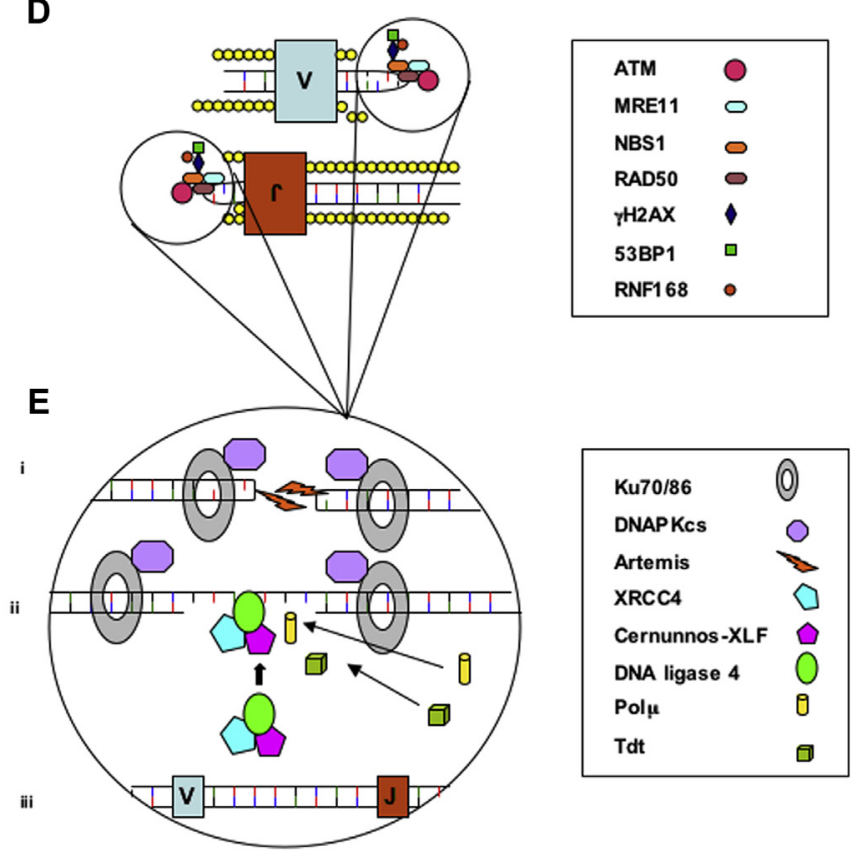

FIG E1. V(D)J Recombination. A, DNA is uncoiled at transcription "factories" within the cell, where the associated recombination and repair proteins colocalize. B, Lymphoid-specific RAG1/2 proteins recognize and bind the recombination signal sequences (RSS) that flank $V(D) J$ gene segments and introduce site-specific DNA-dsbs. C, The phosphorylated blunt signal ends and the covalently sealed hairpin intermediate of the coding end are held together by the RAG complex. D, The MRN complex binds the broken DNA ends and activates ATM, which initiates cell-cycle arrest and attraction of the repair proteins. H2AX, 53BP1, and RNF168, with other proteins, stabilize the damaged chromatin. E, $i$, The Ku70/Ku80 heterodimer binds the coding ends and recruits DNA protein kinase catalytic subunit (DNA-PKCS) and Artemis, which is required to open the hairpin intermediates. The covalently sealed hairpin intermediate is randomly nicked by the DNA-PKcs/Artemis complex, which generates a single-strand break with $3^{\prime}$ or $5^{\prime}$ overhangs. ii, XRCC4, LIG4, and cernunnos-XLF coassociate and are recruited to the ends. The signal ends are directly ligated by the XRCC4/DNA-LIG4/cernunnos-XLF complex. The opened hairpin intermediate is modified by polymerases, exonucleases, and the lymphoid-specific terminal deoxynucleotidyl transferase (TdT). iii, Repair and ligation by the XRCC4/DNA-LIG4/cernunnos-XLF complex. Reproduced with permission from Ussowicz et al. ${ }^{\text {E17 }}$ 
TABLE E1. Characteristics of patients with LIG4 ${ }^{\mathrm{E} 1-\mathrm{E} 8}$

\begin{tabular}{|c|c|c|c|c|c|c|c|c|}
\hline Patient & $\begin{array}{c}\text { Age (mo) } \\
\text { at HSCT/sex }\end{array}$ & Indication & $\begin{array}{l}\text { Donor/stem } \\
\text { cell source }\end{array}$ & Conditioning & aGvHD & Complications & $\begin{array}{l}\text { Follow-up } \\
\text { (mo) }\end{array}$ & Outcome \\
\hline \multicolumn{9}{|l|}{ New cases } \\
\hline \multicolumn{9}{|l|}{1} \\
\hline Transplant 1 & $5 / \mathrm{M}$ & Infection & MUD & Alemtuzumab, $1 \mathrm{mg} / \mathrm{kg}$ & Nil & Initial graft failure, chronic lung disease & - & Alive \\
\hline Transplant 2 & $9 / \mathrm{M}$ & Graft failure & $\begin{array}{l}\text { CB } \\
\text { MUD } \\
\text { BM }\end{array}$ & $\begin{array}{l}\text { Flu, } 150 \mathrm{mg} / \mathrm{m}^{2 *} \\
\text { Melph, } 70 \mathrm{mg} / \mathrm{m}^{2} \\
\text { Alemtuzumab, } 1 \mathrm{mg} / \mathrm{kg}\end{array}$ & Nil & $\begin{array}{l}\text { EBV viremia and colitis, hypothyroidism, } \\
\text { bronchiolitis obliterans }\end{array}$ & 83 & Alive \\
\hline 2 & $8 / \mathrm{F}$ & $\begin{array}{l}\text { Autoimmunity } \\
\text { Omenn } \\
\text { phenotype }\end{array}$ & $\begin{array}{l}\text { MMUD 5/6 } \\
\text { CB }\end{array}$ & $\begin{array}{l}\text { Flu } 150 \mathrm{mg} / \mathrm{m}^{2} \dagger \\
\text { Cy, } 20 \mathrm{mg} / \mathrm{kg} \\
\text { Alemtuzumab, } 1 \mathrm{mg} / \mathrm{kg}\end{array}$ & $\begin{array}{l}\text { Grade } 2 \text {, } \\
\text { skin and liver }\end{array}$ & Nil & 48 & Alive \\
\hline 3 & $17 / M$ & Pre-emptive & $\begin{array}{l}\text { MUD } \\
\text { BM }\end{array}$ & $\begin{array}{l}\text { Flu, } 150 \mathrm{mg} / \mathrm{m}^{2 *} \\
\quad \text { Melph, } 70 \mathrm{mg} / \mathrm{m}^{2} \\
\text { Alemtuzumab, } 1 \mathrm{mg} / \mathrm{kg}\end{array}$ & $\begin{array}{l}\text { Grade } 3 \text {, } \\
\text { skin and gut }\end{array}$ & $\begin{array}{l}\text { cGvHD, } \\
\text { EBV, and adenovirus viremia colitis, HTN, } \\
\text { cholecystitis }\end{array}$ & 36 & Alive \\
\hline 4 & $18 / \mathrm{M}$ & Infection & $\begin{array}{l}\text { MUD } \\
\text { PBSC } \\
\text { CD34 }^{+} \text {selected }\end{array}$ & $\begin{array}{l}\text { Flu, } 150 \mathrm{mg} / \mathrm{m}^{2 *} \\
\text { Melph, } 140 \mathrm{mg} / \mathrm{m}^{2} \\
\text { ATG (dose NA) }\end{array}$ & Nil & Dilated cardiomyopathy & 83 & Alive \\
\hline 5 & $18 / \mathrm{M}$ & NA & $\begin{array}{l}\text { MUD } 8 / 8 \\
\text { BM }\end{array}$ & $\begin{array}{l}\text { Flu, } 150 \mathrm{mg} / \mathrm{m}^{2} \\
\text { Melph, } 70 \mathrm{mg} / \mathrm{m}^{2} \\
\text { Alemtuzumab, } 1 \mathrm{mg} / \mathrm{kg}\end{array}$ & Grade 3 & NA & 24 & Alive \\
\hline \multicolumn{9}{|l|}{6} \\
\hline Transplant 1 & $21 / \mathrm{M}$ & Infection & MMFD & Nil & Nil & Graft failure & 143 & Alive \\
\hline Transplant 2 & $23 / \mathrm{M}$ & Graft failure & $\begin{array}{l}\text { BM } \\
\text { MMFD } \\
\text { BM }\end{array}$ & $\begin{array}{l}\mathrm{Bu}, 12.9 \mathrm{mg} / \mathrm{kg}^{*} \\
\text { Flu, } 120 \mathrm{mg} / \mathrm{m}^{2} \\
\text { Alemtuzumab, } 0.3 \mathrm{mg} / \mathrm{kg}\end{array}$ & & $\begin{array}{l}\text { Mucositis, left arytenoid cartilage fracture, } \\
\text { synechia of anterior vocal cord }\end{array}$ & & Alive \\
\hline 7 & $20 / \mathrm{F}$ & $\begin{array}{l}\text { Infection } \\
\text { SCID } \\
\text { phenotype }\end{array}$ & $\begin{array}{l}\text { MFD } \\
\text { BM }\end{array}$ & $\begin{array}{l}\text { Flu, } 150 \mathrm{mg} / \mathrm{m}^{2} \dagger \\
\text { Cy, } 20 \mathrm{mg} / \mathrm{kg} \\
\text { Alemtuzumab, } 1 \mathrm{mg} / \mathrm{kg}\end{array}$ & Nil & Sepsis & 2 & Alive \\
\hline 8 & 28/M & $\mathrm{BMF}$ & $\begin{array}{l}\text { MUD } \\
\text { BM }\end{array}$ & $\begin{array}{l}\text { Flu, } 150 \mathrm{mg} / \mathrm{m}^{2 *} \\
\quad \text { Melph, } 70 \mathrm{mg} / \mathrm{m}^{2} \\
\text { Alemtuzumab, } 1 \mathrm{mg} / \mathrm{kg}\end{array}$ & Nil & Nil & 46 & Alive \\
\hline 9 & $28 / \mathrm{F}$ & NA & $\begin{array}{l}\text { MUD 8/8 } \\
\text { BM }\end{array}$ & $\begin{array}{l}\text { Flu, } 150 \mathrm{mg} / \mathrm{m}^{2} \\
\text { Melph, } 70 \mathrm{mg} / \mathrm{m}^{2} \\
\text { Alemtuzumab, } 1 \mathrm{mg} / \mathrm{kg}\end{array}$ & Nil & NA & 36 & Alive \\
\hline 10 & $31 / \mathrm{F}$ & Infection & $\begin{array}{l}\text { MMFD } \\
\text { BM }\end{array}$ & Nil & $\begin{array}{l}\text { Grade } 3 \text {, } \\
\text { skin, gut }\end{array}$ & Developmental delay & 142 & Alive \\
\hline 11 & $43 / \mathrm{F}$ & BMF & $\begin{array}{l}\text { MUD } \\
\text { BM, buffy coat enrichment, } \\
\text { plasma reduction }\end{array}$ & $\begin{array}{l}\text { Flu, } 150 \mathrm{mg} / \mathrm{m}^{2} \dagger \\
\text { Cy, } 40 \mathrm{mg} / \mathrm{kg} \\
\text { Alemtuzumab, } 1 \mathrm{mg} / \mathrm{kg}\end{array}$ & Nil & Nil & 24 & Alive \\
\hline 12 & $47 / M$ & Infection & $\begin{array}{l}\text { MFD } \\
\text { BM }\end{array}$ & $\begin{array}{l}\text { Flu, } 150 \mathrm{mg} / \mathrm{m}^{2} \dagger \\
\text { Cy, } 20 \mathrm{mg} / \mathrm{kg} \\
\text { ATG, } 30 \mathrm{mg} / \mathrm{kg}\end{array}$ & Nil & Nil & 15 & Alive \\
\hline 13 & $52 / \mathrm{F}$ & Infection & $\begin{array}{l}\text { MMFD 9/10 } \\
\text { BM }\end{array}$ & $\begin{array}{l}\text { Flu, } 150 \mathrm{mg} / \mathrm{m}^{2} \dagger \\
\text { Cy, } 20 \mathrm{mg} / \mathrm{kg} \\
\text { Alemtuzumab, } 1 \mathrm{mg} / \mathrm{kg}\end{array}$ & Nil & CMV viremia, EBV-PTLD & 50 & Alive \\
\hline
\end{tabular}




\begin{tabular}{|c|c|c|c|c|c|c|c|c|}
\hline Patient & $\begin{array}{c}\text { Age (mo) } \\
\text { at HSCT/sex }\end{array}$ & Indication & $\begin{array}{c}\text { Donor/stem } \\
\text { cell source }\end{array}$ & Conditioning & aGvHD & Complications & $\begin{array}{l}\text { Follow-up } \\
(\mathrm{mo})\end{array}$ & Outcome \\
\hline 14 & $54 / \mathrm{M}$ & $\begin{array}{l}\text { Infection } \\
\text { Autoimmunity } \\
\text { BMF }\end{array}$ & $\begin{array}{l}\text { MSD } \\
\text { BM }\end{array}$ & $\begin{array}{l}\text { Flu, } 150 \mathrm{mg} / \mathrm{m}^{2} \dagger \\
\text { Cy, } 40 \mathrm{mg} / \mathrm{kg} \\
\text { ATG, } 7.5 \mathrm{mg} / \mathrm{kg}\end{array}$ & Grade 1, skin & $\begin{array}{l}\text { Limited cGvHD (resolved) } \\
\text { Autoimmune hypothyroidism }\end{array}$ & 45 & Alive \\
\hline 15 & $75 / \mathrm{F}$ & $\mathrm{BMF}$ & $\begin{array}{l}\text { MUD 9/10 } \\
\text { BM }\end{array}$ & $\begin{array}{l}\mathrm{Bu}, 2.4 \mathrm{mg} / \mathrm{kg} \dagger \\
\text { Flu, } 180 \mathrm{mg} / \mathrm{m}^{2} \\
\mathrm{Cy}, 40 \mathrm{mg} / \mathrm{kg} \\
\text { Alemtuzumab, } \\
\quad 1.5 \mathrm{mg} / \mathrm{kg}\end{array}$ & Nil & Nil & 22 & Alive \\
\hline 16 & $83 / \mathrm{F}$ & BMF & $\begin{array}{l}\text { MUD } \\
\text { PBSC }\end{array}$ & $\begin{array}{l}\text { Flu, } 150 \mathrm{mg} / \mathrm{m}^{2} \dagger \\
\mathrm{Cy}, 20 \mathrm{mg} / \mathrm{kg} \\
\text { Alemtuzumab, } \\
\quad 1 \mathrm{mg} / \mathrm{kg}\end{array}$ & Nil & Nil & 21 & Alive \\
\hline 17 & $116 / \mathrm{F}$ & BMF & $\begin{array}{l}\text { MMUD } \\
5 / 6 \\
\text { BM }\end{array}$ & $\begin{array}{l}\text { Flu, } 150 \mathrm{mg} / \mathrm{m}^{2} \dagger \\
\text { Cy, } 40 \mathrm{mg} / \mathrm{kg} \\
\text { ATG, } 10 \mathrm{mg} / \mathrm{kg}\end{array}$ & Grade 1 , skin & $\begin{array}{l}\text { PRES } \\
\text { cGvHD, skin and mucosa } \\
\text { Mixed chimerism }\end{array}$ & 12 & Alive \\
\hline 18 & $120 / \mathrm{M}$ & Infection & $\begin{array}{l}\text { MSD } \\
\text { BM }\end{array}$ & $\begin{array}{l}\text { Flu, } 40 \mathrm{mg} / \mathrm{m}^{2} \dagger \\
\text { Cy, } 24 \mathrm{mg} / \mathrm{kg} \\
\text { ATG, } 3 \mathrm{mg} / \mathrm{kg}\end{array}$ & Nil & Nil & 22 & Alive \\
\hline 19 & $11 / \mathrm{M}$ & $\begin{array}{l}\text { Infection } \\
\text { SCID phenotype }\end{array}$ & $\begin{array}{l}\text { MUD } \\
\text { CB }\end{array}$ & $\begin{array}{l}\text { Flu, } 90 \mathrm{mg} / \mathrm{m}^{2 *} \\
\text { Melph, } 114 \mathrm{mg} / \mathrm{m}^{2}\end{array}$ & Nil & MOF & 2 & Dead \\
\hline 20 & $22 / \mathrm{F}$ & Infection & $\begin{array}{l}\text { MRD } \\
\text { BM }\end{array}$ & $\begin{array}{l}\mathrm{Bu}, 4 \mathrm{mg} / \mathrm{kg}^{*} \\
\text { Flu, } 120 \mathrm{mg} / \mathrm{m}^{2} \\
\text { Melph, } 140 \mathrm{mg} / \mathrm{m}^{2}\end{array}$ & Nil & Heart failure, multiorgan failure from $\mathrm{D}+1$ & $5 \mathrm{~d}$ & Dead \\
\hline 21 & $33 / \mathrm{M}$ & Infection & MUDBM & $\begin{array}{l}\text { Flu, } 150 \mathrm{mg} / \mathrm{m}^{2 *} \\
\text { Melph, } 140 \mathrm{mg} / \mathrm{m}^{2} \\
\text { ATG (dose NA) }\end{array}$ & $\begin{array}{l}\text { Grade } 2, \\
\text { skin and gut }\end{array}$ & VOD, mucositis, died MOF, GI bleeding & NA & Dead \\
\hline 22 & $49 / \mathrm{F}$ & $\begin{array}{l}\text { Infection } \\
\text { BMF }\end{array}$ & $\begin{array}{l}\text { MMUD } \\
\text { CB }\end{array}$ & $\begin{array}{l}\text { Flu, } 150 \mathrm{mg} / \mathrm{m}^{2} \dagger \\
\text { Cy, } 40 \mathrm{mg} / \mathrm{kg} \\
\text { ATG, } 10 \mathrm{mg} / \mathrm{kg}\end{array}$ & Grade 3, gut & Pericardial effusion, SVT, MAS & 7 & Dead \\
\hline 23 & $8 / \mathrm{M}$ & Pre-emptive & $\begin{array}{l}\text { MUD } \\
\text { BM }\end{array}$ & $\begin{array}{l}\text { Treo, } 42 \mathrm{~g} / \mathrm{m}^{2} \\
\text { Flu, } 150 \mathrm{mg} / \mathrm{m}^{2} \\
\text { ATG, } 10 \mathrm{mg} / \mathrm{kg}\end{array}$ & $\begin{array}{l}\text { Grade } 3 \text {, } \\
\text { skin and gut }\end{array}$ & $\begin{array}{l}\text { Norovirus, TPN dependence, graft failure, } \\
\text { osteopenic fractures, HTN, rhinovirus, } \\
\text { MOF }\end{array}$ & 8 & Dead \\
\hline 24 & $10 / \mathrm{F}$ & Infection & $\begin{array}{l}\text { Paternal haploidentical } \\
\text { PBSC CD } 34^{+} \text {selected }\end{array}$ & $\begin{array}{l}\text { Flu, } 120 \mathrm{mg} / \mathrm{m}^{2} \\
\text { Melph, } 140 \mathrm{mg} / \mathrm{m}^{2} \\
\text { TT, } 10 \mathrm{mg} / \mathrm{kg}\end{array}$ & Grade 1, skin & GI and pulmonary hemorrhage & 1 & Dead \\
\hline 25 & $13 / \mathrm{M}$ & $\begin{array}{l}\text { Infection } \\
\text { SCID phenotype }\end{array}$ & $\begin{array}{l}\text { MMUD 9/10 } \\
\text { BM }\end{array}$ & $\begin{array}{l}\text { Flu, } 150 \mathrm{mg} / \mathrm{m}^{2} \dagger \\
\text { TT, } 15 \mathrm{mg} / \mathrm{kg} \\
\text { ATG, } 10 \mathrm{mg} / \mathrm{kg}\end{array}$ & $\begin{array}{l}\text { Grade 3, skin, } \\
\text { gut, and liver }\end{array}$ & $\begin{array}{l}\text { Pseudomonas aeruginosa, RSV, EBV, } \\
\text { CMV, capillary leak syndrome } \\
\text { Pneumopathy }\end{array}$ & 5 & Dead \\
\hline 26 & $60 / \mathrm{M}$ & BMF & $\begin{array}{l}\text { Maternal } \\
\mathrm{CD}^{+} 4^{+} \text {haploidentical }\end{array}$ & $\begin{array}{l}\text { Flu, } 200 \mathrm{mg} / \mathrm{m} \\
\mathrm{Cy}, 20 \mathrm{mg} / \mathrm{kg} \\
\text { TT, } 5 \mathrm{mg} / \mathrm{kg} \\
\text { ATG, } 3 \mathrm{mg} / \mathrm{kg}\end{array}$ & Nil & $\begin{array}{l}\text { Rejection } \\
\text { Fungal pneumonia }\end{array}$ & 6 & Dead \\
\hline
\end{tabular}


TABLE E1. (Continued)

\begin{tabular}{|c|c|c|c|c|c|c|c|c|}
\hline Patient & $\begin{array}{c}\text { Age }(\mathrm{mo}) \\
\text { at HSCT/sex }\end{array}$ & Indication & $\begin{array}{c}\text { Donor/stem } \\
\text { cell source }\end{array}$ & Conditioning & aGvHD & Complications & $\begin{array}{l}\text { Follow-up } \\
(\mathrm{mo})\end{array}$ & Outcome \\
\hline \multicolumn{9}{|c|}{ Updated cases } \\
\hline $27^{\mathrm{E} 7}$ & $49 / M$ & Infection & $\begin{array}{l}\text { MUD } \\
\text { PBSC }\end{array}$ & $\begin{array}{l}\text { Flu, } 150 \mathrm{mg} / \mathrm{m}^{2} \dagger \\
\text { Cy, } 40 \mathrm{mg} / \mathrm{mg} \\
\text { Alemtuzumab, } 0.6 \mathrm{mg} / \mathrm{kg} \\
\text { YTH24/54, } 1.6 \mathrm{mg} / \mathrm{kg}\end{array}$ & $\begin{array}{l}\text { Grade } 2 \text {, } \\
\text { skin and gut }\end{array}$ & Autoimmune hypothyroidism & 93 & Alive \\
\hline $28^{\mathrm{E} 6}$ & $6 / \mathrm{F}$ & $\begin{array}{l}\text { Infection } \\
\text { SCID phenotype }\end{array}$ & $\begin{array}{l}\text { MUD } \\
\text { BM }\end{array}$ & $\begin{array}{l}\mathrm{Bu}, 16 \mathrm{mg} / \mathrm{kg} \\
\mathrm{Cy}, 200 \mathrm{mg} / \mathrm{kg}\end{array}$ & $\begin{array}{l}\text { Grade } 4, \\
\text { skin and gut }\end{array}$ & $\begin{array}{l}\text { cGvHD respiratory failure, cardiac } \\
\text { hypertrophy, renal failure, EBV, } \\
\text { developmental delay, increased ICP, } \\
\text { tube feed, optic neuritis }\end{array}$ & 103 & Alive \\
\hline $29^{\mathrm{E} 1}$ & $552 / \mathrm{M}$ & $\begin{array}{l}\text { BMF } \\
\text { MDS }\end{array}$ & $\begin{array}{l}\text { MSD } \\
\text { BM }\end{array}$ & $\begin{array}{l}\mathrm{Bu}, 12.8 \mathrm{mg} / \mathrm{kg} \\
\mathrm{Cy}, 120 \mathrm{mg} / \mathrm{kg}\end{array}$ & Nil & $\begin{array}{l}\text { Severe mucositis, CMV } \\
\text { cGvHD }\end{array}$ & $?$ & Alive \\
\hline $30^{\mathrm{E} 2}$ & $19 / \mathrm{F}$ & $\begin{array}{l}\text { Infection } \\
\text { SCID phenotype }\end{array}$ & $\begin{array}{l}\text { MMUD } \\
\text { BM (TCD) }\end{array}$ & $\begin{array}{l}\mathrm{Bu}, 16 \mathrm{mg} / \mathrm{kg} \\
\mathrm{Cy}, 200 \mathrm{mg} / \mathrm{kg} \\
\text { ATG, } 10 \mathrm{mg} / \mathrm{kg}\end{array}$ & Nil & EBV-PTLD & 2 & Dead \\
\hline $31^{\mathrm{E} 2}$ & $2.5 / \mathrm{F}$ & $\begin{array}{l}\text { Pre-emptive } \\
\text { SCID phenotype }\end{array}$ & $\begin{array}{l}\text { MMUD } \\
\text { BM } \\
3 / 6 \\
\text { TCD }\end{array}$ & $\begin{array}{l}\mathrm{Bu}, 15 \mathrm{mg} / \mathrm{kg} \\
\mathrm{Cy}, 200 \mathrm{mg} / \mathrm{kg} \\
\text { ATG, } 10 \mathrm{mg} / \mathrm{kg}\end{array}$ & Nil & $\begin{array}{l}\text { VOD } \\
\text { Pneumopathy }\end{array}$ & 1.5 & Dead \\
\hline $32^{\mathrm{E} 8}$ & $212 / \mathrm{M}$ & $\mathrm{BMF}$ & $\begin{array}{l}\text { TCR } \alpha / \beta \text { PBSC } \\
\text { haploidentical } \\
\text { mother }\end{array}$ & $\begin{array}{l}\text { Flu, } 180 \mathrm{mg} / \mathrm{m}^{2 *} \\
\text { Cy, } 60 \mathrm{mg} / \mathrm{kg} \\
\text { ATG, } 2.5 \mathrm{mg} / \mathrm{kg}\end{array}$ & $\begin{array}{l}\text { Grade 3, } \\
\text { GI }\end{array}$ & $\begin{array}{l}\text { Poor immunoreconstitution, BK } \\
\text { viral infection acute renal failure }\end{array}$ & 12 & Dead \\
\hline \multicolumn{9}{|c|}{ Published } \\
\hline $33^{\mathrm{E} 5}$ & $132 / \mathrm{F}$ & BMF & $\begin{array}{l}\text { MSD } \\
\text { BM }\end{array}$ & $\begin{array}{l}\text { Flu, } 120 \mathrm{mg} / \mathrm{m}^{2} \dagger \\
\text { Cy, } 40 \mathrm{mg} / \mathrm{kg} \\
\text { ATG, } 60 \mathrm{mg} / \mathrm{kg}\end{array}$ & Nil & Delayed puberty & 60 & Alive \\
\hline $34^{\mathrm{E} 3}$ & $4 / \mathrm{F}$ & SCID phenotype & $\begin{array}{l}\text { MUD } \\
\text { BM }\end{array}$ & $\begin{array}{l}\text { Flu (dose NA) } \\
\text { TT (dose NA) }\end{array}$ & Nil & Severe HUS, with renal impairment & 8 & Alive \\
\hline $35^{\mathrm{E} 4}$ & $18 / \mathrm{F}$ & Infection & $\begin{array}{l}\text { MSD } \\
\text { cord }\end{array}$ & $\begin{array}{l}\mathrm{Bu}, 20 \mathrm{mg} / \mathrm{kg} \\
\mathrm{Cy}, 200 \mathrm{mg} / \mathrm{kg}\end{array}$ & Nil & Died before HSCT, VOD, respiratory arrest & - & Dead \\
\hline $36^{\mathrm{E} 3}$ & $24 / \mathrm{F}$ & $\begin{array}{l}\text { Infection } \\
\text { Autoimmunity } \\
\text { Malignancy }\end{array}$ & & $\begin{array}{l}\text { Myeloablative } \\
\text { No details available }\end{array}$ & & $\begin{array}{l}\text { Died during conditioning } \\
\text { MOF } \\
\text { Aspergillosis }\end{array}$ & - & Dead \\
\hline
\end{tabular}

ATG, Anti-thymocyte globulin; $B M$, bone marrow; $B M F$, bone marrow failure; $B u$, busulphan; $C B$, cord blood; $C M V$, cytomegalovirus; $C y$, cyclophosphamide; $F l u$, fludarabine; $G I$, gastrointestinal; $H S C T$, hematopoietic stem cell transplant; $H T N$, hypertension; $H U S$, hemolytic uremic syndrome; $I C P$, intracranial pressure; $M A S$, macrophage activation syndrome; $M e l p h$, melphalan; $M F D$, matched family donor; $M M F D$, mismatched family donor; $M O F$, multiorgan failure; $M U D$, matched unrelated donor; NA, not available; $P B S C$, peripheral blood stem cells; $P R E S$, posterior reversible encephalopathy syndrome; $R S V$, respiratory syncytial virus; SVT, supraventricular tachycardia; $T C D$, T cell depleted; TCR $\alpha / \beta$, T-cell receptor alpha/beta depletion; TPN, total parenteral nutrition; Treo, treosulfan; TT, thiotepa; VOD, veno-occlusive disease; YTH24/54, anti-CD45 mAbs.

*RIC regimen.

$\dagger$ Fanconi or modified Fanconi regimen

\$MAC regimen. 
TABLE E2. Characteristics of patients with defects in $N B N^{E 9-E 12}$

\begin{tabular}{|c|c|c|c|c|c|c|c|c|}
\hline Patient & $\begin{array}{l}\text { Age (mo) at } \\
\text { HSCT/sex }\end{array}$ & Indication & $\begin{array}{l}\text { Donor/stem } \\
\text { cell source }\end{array}$ & Conditioning & aGvHD & Complications & $\begin{array}{l}\text { Follow-up } \\
\text { (mo) }\end{array}$ & Outcome \\
\hline \multicolumn{9}{|c|}{ New cases } \\
\hline 37 & $45 / \mathrm{F}$ & Autoimmunity & $\begin{array}{l}\text { MSD } \\
\text { BM }\end{array}$ & $\begin{array}{l}\text { Alemtuzumab, }{ }^{\dagger} 1 \mathrm{mg} / \mathrm{kg} \\
\text { Flu, } 150 \mathrm{mg} / \mathrm{m}^{2} \\
\text { Cy, } 20 \mathrm{mg} / \mathrm{kg}\end{array}$ & Grade 2, skin & AIHA & 14 & Alive \\
\hline 38 & 69/M & Malignancy & $\begin{array}{l}\text { TCR } \alpha / \beta \text { PBSC } \\
\text { MUD } 9 / 10\end{array}$ & $\begin{array}{l}\text { Bu, } 4 \mathrm{mg} / \mathrm{kg} * \\
\text { Flu, } 150 \mathrm{mg} / \mathrm{m}^{2} \\
\text { Cy, } 30 \mathrm{mg} / \mathrm{kg} \\
\text { ATG, } 5 \mathrm{mg} / \mathrm{kg} \\
\text { Rituximab, } 100 \mathrm{mg} / \mathrm{m}^{2}\end{array}$ & Nil & $\begin{array}{l}\text { Hepatitis } \\
\text { CMV viremia }\end{array}$ & 5 & Alive \\
\hline 39 & 71/M & Infection & $\begin{array}{l}\text { TCR } \alpha / \beta \text { PBSC } \\
9 / 10 \text { sibling donor }\end{array}$ & $\begin{array}{l}\mathrm{Bu}, 4 \mathrm{mg} / \mathrm{kg}^{*} \\
\text { Flu, } 150 \mathrm{mg} / \mathrm{m}^{2} \\
\mathrm{Cy}, 20 \mathrm{mg} / \mathrm{kg} \\
\text { ATG, } 5 \mathrm{mg} / \mathrm{kg} \\
\text { Rituximab, } 100 \mathrm{mg} / \mathrm{m}^{2}\end{array}$ & Nil & Nil & 2 & Alive \\
\hline 40 & 90/M & Malignancy & $\begin{array}{c}\text { TCR } \alpha / \beta \text { PBSC } \\
\text { MUD } 10 / 10\end{array}$ & $\begin{array}{l}\text { Bu, } 4 \mathrm{mg} / \mathrm{kg}^{*} \\
\text { Flu, } 150 \mathrm{mg} / \mathrm{m}^{2} \\
\text { Cy, } 40 \mathrm{mg} / \mathrm{kg} \\
\text { ATG, } 5 \mathrm{mg} / \mathrm{kg} \\
\text { Rituximab, } 100 \mathrm{mg} / \mathrm{m}^{2}\end{array}$ & Nil & Hepatitis & 6 & Alive \\
\hline 41 & $107 / \mathrm{F}$ & Pre-emptive & $\begin{array}{l}\text { MUD } 9 / 10 \\
\text { PBSC } \\
\text { CD34+ with T-cell } \\
\text { add-back } 1 \times 10^{8} / \mathrm{kg}\end{array}$ & $\begin{array}{l}\mathrm{Bu}, 2 \mathrm{mg} / \mathrm{kg} \dagger \\
\mathrm{Flu}, 180 \mathrm{mg} / \mathrm{kg} \\
\mathrm{Cy}, 20 \mathrm{mg} / \mathrm{kg} \\
\text { Alemtuzumab, } 0.5 \mathrm{mg} / \mathrm{kg}\end{array}$ & Nil & Secondary graft loss & 14 & $\begin{array}{c}\text { Alive with } \\
\text { disease }\end{array}$ \\
\hline 42 & $144 / M$ & Malignancy & $\begin{array}{l}\text { MSD } \\
\text { BM }\end{array}$ & $\begin{array}{l}\text { Bu, } 4 \mathrm{mg} / \mathrm{kg}^{*} \\
\mathrm{Flu}, 150 \mathrm{mg} / \mathrm{m}^{2} \\
\mathrm{Cy}, 20 \mathrm{mg} / \mathrm{kg} \\
\text { ATG, } 5 \mathrm{mg} / \mathrm{kg}\end{array}$ & Grade 1 , skin & $\begin{array}{l}\text { Norovirus, adenovirus } \\
\text { enterocolitis }\end{array}$ & 16 & Alive \\
\hline 43 & $205 / F$ & EBV-associated LPD & $\begin{array}{l}\text { MSD } \\
\text { BM }\end{array}$ & $\begin{array}{l}\mathrm{Bu}, 4 \mathrm{mg} / \mathrm{kg} * \\
\mathrm{Flu}, 150 \mathrm{mg} / \mathrm{m}^{2} \\
\text { Cy, } 30 \mathrm{mg} / \mathrm{kg} \\
\text { ATG, rituximab }\end{array}$ & Nil & EBV-PTLD & 6 & Alive \\
\hline 44 & $228 / \mathrm{M}$ & NA & $\begin{array}{l}\text { MUD 8/8 } \\
\text { PBSC }\end{array}$ & $\begin{array}{l}\text { TBI }(2 \mathrm{~Gy}) \ddagger \\
\text { Flu, } 150 \mathrm{mg} / \mathrm{m}^{2}\end{array}$ & Grade 2 & cGvHD & 59 & Alive \\
\hline 45 & $60 / \mathrm{F}$ & Malignancy & $\begin{array}{l}\text { MUD } \\
\text { PBSC } \\
\text { TCR } \alpha / \beta\end{array}$ & $\begin{array}{l}\mathrm{Bu}, 4 \mathrm{mg} / \mathrm{kg}^{*} \\
\text { Flu, } 150 \mathrm{mg} / \mathrm{m}^{2} \\
\mathrm{Cy}, 40 \mathrm{mg} / \mathrm{kg} \\
\text { ATG, } 5 \mathrm{mg} / \mathrm{kg} \\
\text { Rituximab, } 100 \mathrm{mg} / \mathrm{m}^{2}\end{array}$ & Grade 1 , skin & $\begin{array}{l}\text { Mucositis grade } 2, \\
\text { relapse PTCL }\end{array}$ & 3 & Dead \\
\hline 46 & $136 / \mathrm{F}$ & Malignancy & $\begin{array}{l}\text { MMFD } \\
\text { PBSC }\end{array}$ & $\begin{array}{l}\text { Melph, } 140 \mathrm{mg} / \mathrm{m}^{2} * \\
\text { Flu, } 120 \mathrm{mg} / \mathrm{m}^{2} \\
\text { Alemtuzumab, } 1 \mathrm{mg} / \mathrm{kg}\end{array}$ & Nil & VOD, MOF, sepsis & 2 & Dead \\
\hline 47 & $204 / \mathrm{F}$ & BMF & $\begin{array}{l}\text { MUD } \\
\text { PBSC } \\
\text { TCR } \alpha / \beta\end{array}$ & $\begin{array}{l}\mathrm{Bu}, 4 \mathrm{mg} / \mathrm{kg}^{*} \\
\text { Flu, } 150 \mathrm{mg} / \mathrm{m}^{2} \\
\text { Cy, } 40 \mathrm{mg} / \mathrm{kg} \\
\text { ATG, } 5 \mathrm{mg} / \mathrm{kg} \\
\text { Rituximab, } 100 \mathrm{mg} / \mathrm{m}^{2}\end{array}$ & Nil & $\begin{array}{l}\text { Rejected } 10 \text { mo } \\
\text { Developed T-cell } \\
\text { lymphoma }\end{array}$ & 16 & Dead \\
\hline
\end{tabular}


TABLE E2. (Continued)

\begin{tabular}{|c|c|c|c|c|c|c|c|c|}
\hline Patient & $\begin{array}{l}\text { Age }(\mathrm{mo}) \text { at } \\
\mathrm{HSCT} / \mathrm{sex}\end{array}$ & Indication & $\begin{array}{l}\text { Donor/stem } \\
\text { cell source }\end{array}$ & Conditioning & aGvHD & Complications & $\begin{array}{l}\text { Follow-up } \\
\text { (mo) }\end{array}$ & Outcome \\
\hline \multicolumn{9}{|c|}{ Updated cases } \\
\hline $48^{\mathrm{E} 9, \mathrm{E} 11}$ & $27 / \mathrm{F}$ & Infection & $\begin{array}{l}\text { MSD } \\
\text { BM }\end{array}$ & $\begin{array}{l}\text { Alemtuzumab, } † \\
1 \mathrm{mg} / \mathrm{kg} \\
\text { Flu, } 150 \mathrm{mg} / \mathrm{m}^{2} \\
\text { Cy, } 20 \mathrm{mg} / \mathrm{kg}\end{array}$ & Nil & $\begin{array}{l}\text { Autoimmune } \\
\text { hyperthyroidism }\end{array}$ & 102 & Alive \\
\hline $49^{\mathrm{E} 9, \mathrm{E} 11}$ & $42 / \mathrm{M}$ & Pre-emptive & $\begin{array}{l}\text { MFD 10/10 } \\
\text { BM }\end{array}$ & $\begin{array}{l}\text { Thoracoabdominal } \$ \\
\text { irradiation, } 5 \mathrm{~Gy} \\
\mathrm{Cy}, 20 \mathrm{mg} / \mathrm{kg} \\
\text { Alemtuzumab, } 1 \mathrm{mg} / \mathrm{kg}\end{array}$ & Nil & $\begin{array}{l}\text { ADV, CMV } \\
\text { Mucositis } \\
\text { Mixed chimerism }\end{array}$ & 150 & Alive \\
\hline $50^{\mathrm{E} 11}$ & $77 / \mathrm{F}$ & Malignancy & $\begin{array}{l}\text { MUD } \\
\text { BM }\end{array}$ & $\begin{array}{l}\text { Flu, } 150 \mathrm{mg} / \mathrm{m}^{2} \dagger \\
\text { Cy, } 20 \mathrm{mg} / \mathrm{kg} \\
\text { Alemtuzumab, } 1 \mathrm{mg} / \mathrm{kg}\end{array}$ & Grade 1, skin & Nil & 29 & Alive \\
\hline $51^{\mathrm{E} 11}$ & $110 / \mathrm{M}$ & Malignancy & $\begin{array}{l}\text { MFD } \\
\text { BM }\end{array}$ & $\begin{array}{l}\text { Flu, } 150 \mathrm{mg} / \mathrm{m}^{2} \dagger \\
\text { Cy, } 40 \mathrm{mg} / \mathrm{kg} \\
\text { ATG, } 70 \mathrm{mg} / \mathrm{kg} \\
\text { Rituximab, } 750 \mathrm{mg} / \mathrm{m}^{2}\end{array}$ & Grade 3, skin & $\begin{array}{l}\text { cGvHD skin, liver } \\
\text { CMV reactivation }\end{array}$ & 48 & Alive \\
\hline $52^{\mathrm{E} 9}$ & $240 / \mathrm{M}$ & Malignancy & $\begin{array}{l}\text { MUD } \\
\text { PBSC }\end{array}$ & $\begin{array}{l}\text { Melph, } 140 \mathrm{mg} / \mathrm{m}^{2} * \\
\text { Flu, } 125 \mathrm{mg} / \mathrm{m}^{2} \\
\text { ATG, } 60 \mathrm{mg} / \mathrm{kg}\end{array}$ & Grade 1, skin & Nil & 99 & Alive \\
\hline $53^{\mathrm{E} 12}$ & $185 / \mathrm{M}$ & Malignancy & $\begin{array}{l}\text { MSD } \\
\text { BM }\end{array}$ & $\begin{array}{l}\text { Melph, } 140 \mathrm{mg} / \mathrm{m}^{2} * \\
\text { Flu, } 150 \mathrm{mg} / \mathrm{m}^{2} \\
\text { Alemtuzumab, } 1 \mathrm{mg} / \mathrm{kg}\end{array}$ & Grade 1 , skin and gut & Toxoplasmosis & 1 & Dead \\
\hline \multicolumn{9}{|c|}{ Published cases } \\
\hline $54^{\mathrm{E} 10}$ & $19 / \mathrm{F}$ & Infection & $\begin{array}{l}\text { MUD } \\
\text { CB }\end{array}$ & $\begin{array}{l}\text { ATG, } 10 \mathrm{mg} / \mathrm{kg}^{\dagger} \\
\text { Flu, } 150 \mathrm{mg} / \mathrm{m}^{2} \\
\text { Cy, } 20 \mathrm{mg} / \mathrm{kg}\end{array}$ & Nil & Nil & 34 & Alive \\
\hline $55^{\mathrm{E} 11}$ & $46 / F$ & Infection & $\begin{array}{l}\text { MUD } \\
\text { PBSC }\end{array}$ & $\begin{array}{l}\text { Flu, } 150 \mathrm{mg} / \mathrm{m}^{2} \dagger \\
\text { Cy, } 20 \mathrm{mg} / \mathrm{kg} \\
\text { Alemtuzumab, } 1 \mathrm{mg} / \mathrm{kg}\end{array}$ & $\begin{array}{l}\text { Grade 2, } \\
\text { skin and gut }\end{array}$ & Nil & 48 & Alive \\
\hline $56^{\mathrm{E} 11}$ & $72 / \mathrm{F}$ & Malignancy & $\begin{array}{l}\text { MUD } \\
\text { PBSC }\end{array}$ & $\begin{array}{l}\mathrm{Bu}, 2 \mathrm{mg} / \mathrm{kg} \dagger \\
\text { Flu, } 150 \mathrm{mg} / \mathrm{m}^{2} \\
\text { ATG, } 7.5 \mathrm{mg} / \mathrm{kg}\end{array}$ & Nil & Nil & 17 & Alive \\
\hline $57^{\mathrm{E} 9, \mathrm{E} 11}$ & $165 / \mathrm{M}$ & Malignancy & $\begin{array}{l}\text { MUD } \\
\text { PBSC }\end{array}$ & $\begin{array}{l}\mathrm{Bu}, 2 \mathrm{mg} / \mathrm{kg} \dagger \\
\text { Flu, } 150 \mathrm{mg} / \mathrm{m}^{2} \\
\text { ATG, } 60 \mathrm{mg} / \mathrm{kg}\end{array}$ & Grade 2, skin & $\begin{array}{l}\text { cGvHD } \\
\text { Mild hemorrhagic cystitis }\end{array}$ & 81 & Alive \\
\hline $58^{\mathrm{E} 9}$ & $174 / \mathrm{M}$ & Malignancy & $\begin{array}{l}\text { MMFD } \\
\text { TCD } \\
\text { PBSC }\end{array}$ & $\begin{array}{l}\text { Flu, } 160 \mathrm{mg} / \mathrm{m}^{2} \\
\text { TT, } 10 \mathrm{mg} / \mathrm{kg} \\
\text { Melph, } 70 \mathrm{mg} / \mathrm{m}^{2}\end{array}$ & Nil & $\begin{array}{l}\text { Mucositis, ITP, } \\
\text { sepsis, adeno } \\
\text { cryptosporidiosis }\end{array}$ & 24 & Alive \\
\hline $59^{\mathrm{E} 11}$ & $\begin{array}{l}102 / \mathrm{M} \\
113\end{array}$ & $\begin{array}{l}\text { Malignancy } \\
\text { Malignancy relapse }\end{array}$ & $\begin{array}{l}\text { MSD } \\
\text { BM } \\
\text { MSD } \\
\text { BM }\end{array}$ & $\begin{array}{l}\text { Flu (dose NA)* } \\
\mathrm{Cy}(\text { dose NA) } \\
\mathrm{Bu}, 12 \mathrm{mg} / \mathrm{kg} \$ \\
\mathrm{Cy}, 120 \mathrm{mg} / \mathrm{kg}\end{array}$ & $\begin{array}{l}\text { Nil } \\
\text { Gut }\end{array}$ & $\begin{array}{l}\text { Rejected } \\
\text { Sepsis }\end{array}$ & $\begin{array}{c}11 \\
3\end{array}$ & $\begin{array}{l}\text { Alive } \\
\text { Dead }\end{array}$ \\
\hline $60^{\mathrm{E} 11}$ & $110 / \mathrm{F}$ & Malignancy & $\begin{array}{l}\text { MSD } \\
\text { BM }\end{array}$ & $\begin{array}{l}\mathrm{Bu}, 2 \mathrm{mg} / \mathrm{kg}{ }^{\dagger} \\
\text { Flu, } 150 \mathrm{mg} / \mathrm{m}^{2} \\
\text { ATG (dose NA) }\end{array}$ & Nil & Lymphoma relapse & 2 & Dead \\
\hline
\end{tabular}




\begin{tabular}{|c|c|c|c|c|c|c|c|c|}
\hline Patient & $\begin{array}{l}\text { Age (mo) at } \\
\text { HSCT/sex }\end{array}$ & Indication & $\begin{array}{l}\text { Donor/stem } \\
\text { cell source }\end{array}$ & Conditioning & aGvHD & Complications & $\begin{array}{l}\text { Follow-up } \\
\text { (mo) }\end{array}$ & Outcome \\
\hline $61^{\mathrm{E} 9, \mathrm{E} 11}$ & 192/M & Malignancy & $\begin{array}{l}\text { MSD } \\
\text { PBSC }\end{array}$ & $\begin{array}{l}\mathrm{Bu}, 10 \mathrm{mg} / \mathrm{kg} \\
\mathrm{Cy}, 120 \mathrm{mg} / \mathrm{kg} \\
\mathrm{TT}, 25 \mathrm{mg} / \mathrm{kg}\end{array}$ & Nil & Nil & Sepsis D+5 & Dead \\
\hline $62^{\mathrm{E} 11}$ & $218 / \mathrm{M}$ & Malignancy & $\begin{array}{l}\text { MUD } \\
\text { PBSC }\end{array}$ & $\begin{array}{l}\text { Flu, } 150 \mathrm{mg} / \mathrm{m}^{2 *} \\
\text { Melph, } 140 \mathrm{mg} / \mathrm{m}^{2} \\
\text { ATG (dose NA) }\end{array}$ & Nil & Sepsis & 6 & Dead \\
\hline
\end{tabular}

$A D V$, Adenovirus; $A I H A$, autoimmune hemolytic anemia; $A T G$, anti-thymocyte globulin; $B M$, bone marrow; $B M F$, bone marrow failure; $B u$, busulphan; $C B$, cord blood; $C M V$, cytomegalovirus; $C y$, cyclophosphamide; $F l u$, fludarabine; $G I$, gastrointestinal; $H S C T$, hematopoietic stem cell transplantation; ITP, idiopathic thrombocytopenia; $L P D$, lymphoproliferative disease; $M e l p h$, melphalan; $M F D$, matched family donor; $M M F D$, mismatched family donor; $M O F$, multiorgan failure; $M U D$, matched unrelated donor; $N A$, not available; $P B S C$, peripheral blood stem cells; TBI, total-body irradiation; $T C D$, T cell depleted; TCR $\alpha / \beta$, T-cell receptor $\alpha / \beta$ depletion; $T T$, thiotepa; $V O D$, veno-occlusive disease.

*RIC regimen.

$\dagger$ Fanconi or modified Fanconi regimen.

\$MAC regimen. 
TABLE E3. Characteristics of patients with defects in NHEJ1 $1^{\mathrm{E} 13-\mathrm{E} 15}$

\begin{tabular}{|c|c|c|c|c|c|c|c|c|}
\hline Patient & $\begin{array}{l}\text { Age }(\mathrm{mo}) \text { at } \\
\text { HSCT/sex }\end{array}$ & Indication & $\begin{array}{l}\text { Donor/stem } \\
\text { cell source }\end{array}$ & Conditioning & GvHD & Complications & $\begin{array}{l}\text { Follow-up } \\
\text { (mon) }\end{array}$ & Outcome \\
\hline \multicolumn{9}{|c|}{ New cases } \\
\hline 63 & $5 / \mathrm{M}$ & Infection & $\begin{array}{l}\text { MUD } \\
\text { PBSC }\end{array}$ & $\begin{array}{l}\text { Flu, } 150 \mathrm{mg} / \mathrm{m}^{2 *} \\
\text { Cy, } 20 \mathrm{mg} / \mathrm{kg} \text { Alemtuzumab, } 1 \mathrm{mg} / \mathrm{kg}\end{array}$ & Grade 4 , skin & $\mathrm{ADV}$ & 10 & Alive \\
\hline 64 & $10 / \mathrm{M}$ & Infection & $\begin{array}{l}\text { MSD } \\
\text { BM }\end{array}$ & $\begin{array}{l}\text { Flu, } 150 \mathrm{mg} / \mathrm{m}^{2} * \\
\text { Cy, } 20 \mathrm{mg} / \mathrm{kg}\end{array}$ & Nil & CMV & 3 & Alive \\
\hline 65 & $12 / \mathrm{F}$ & $\begin{array}{l}\text { SCID-like } \\
\text { infection }\end{array}$ & $\begin{array}{l}\text { MSD } \\
\text { BM }\end{array}$ & Nil & Grade 1 aGvHD, skin & Nil & 76 & Alive \\
\hline 66 & $17 / M$ & Infection & $\begin{array}{l}\text { MSD } \\
\text { BM }\end{array}$ & $\begin{array}{l}\text { Cy, } 200 \mathrm{mg} / \mathrm{kg} * \\
\text { ATG, } 60 \mathrm{mg} / \mathrm{kg}\end{array}$ & Nil & Nil & 168 & Alive \\
\hline 67 & 28/M & Infection & $\begin{array}{l}\text { MSD } \\
\text { BM }\end{array}$ & $\begin{array}{l}\text { Cy, } 200 \mathrm{mg} / \mathrm{kg}^{*} \\
\text { ATG, } 60 \mathrm{mg} / \mathrm{kg}\end{array}$ & Nil & Idiopathic pneumonitis & 166 & Alive \\
\hline 68 & $48 / \mathrm{F}$ & Infection & $\begin{array}{l}\text { MMUD } \\
\text { CB }\end{array}$ & $\begin{array}{l}\text { Flu, } 150 \mathrm{mg} / \mathrm{m}^{2} \dagger \\
\text { Cy, } 40 \mathrm{mg} / \mathrm{kg} \\
\text { ATG, } 60 \mathrm{mg} / \mathrm{kg}\end{array}$ & $\begin{array}{l}\text { Grade } 2 \text {, } \\
\text { skin }\end{array}$ & CMV reactivation & 24 & Alive \\
\hline 69 & $100 / \mathrm{F}$ & BMF & $\begin{array}{l}\text { MUD 6/6 } \\
\text { PBSC }\end{array}$ & $\begin{array}{l}\text { Flu, } 150 \mathrm{mg} / \mathrm{m}^{2} \dagger \\
\text { Cy, } 4 \mathrm{mg} / \mathrm{kg} \\
\text { ATG, } 7.5 \mathrm{mg} / \mathrm{kg}\end{array}$ & Grade 2, skin & $\begin{array}{l}\text { Severe skin cGvHD with scleroderma } \\
\text { and joint deformation Cachexia, } \\
\text { esophageal stenosis }\end{array}$ & 86 & Alive \\
\hline 70 & $112 / \mathrm{F}$ & Infection, cytopenia & $\begin{array}{l}\text { MSD } \\
\text { BM }\end{array}$ & $\begin{array}{l}\text { Flu, } 150 \mathrm{mg} / \mathrm{m}^{2} \dagger \\
\text { Cy, } 40 \mathrm{mg} / \mathrm{kg} \\
\text { ATG, } 60 \mathrm{mg} / \mathrm{kg}\end{array}$ & Grade 1 aGvHD, skin & $\begin{array}{l}\text { Lung cGvHD } \\
\text { obstructive lung disease }\end{array}$ & 39 & Alive \\
\hline 71 & $172 / \mathrm{M}$ & $\begin{array}{l}\text { Infection } \\
\text { BMF }\end{array}$ & $\begin{array}{l}\text { MUD 10/10 } \\
\text { BM }\end{array}$ & $\begin{array}{l}\text { ATG, } 15 \mathrm{mg} / \mathrm{kg} \\
\text { Treo, } 42 \mathrm{mg} / \mathrm{m}^{2} \\
\text { Flu, } 160 \mathrm{mg} / \mathrm{m}^{2}\end{array}$ & Nil & Nil & 7 & Alive \\
\hline 72 & $15 / \mathrm{M}$ & $\begin{array}{l}\text { Autoimmune } \\
\text { (AIHA) }\end{array}$ & $\begin{array}{l}\text { MUD } \\
\text { CB }\end{array}$ & $\begin{array}{l}\mathrm{Bu}, 6.4 \mathrm{mg} / \mathrm{kg}^{*} \\
\text { Flu, } 120 \mathrm{mg} / \mathrm{m}^{2} \\
\text { ATG, } 10 \mathrm{mg} / \mathrm{kg}\end{array}$ & Grade 2, skin & Sepsis, EBV, myocarditis & 5 & Dead \\
\hline 73 & $41 / \mathrm{M}$ & Infection & $\begin{array}{l}\text { MUD } \\
\text { BM }\end{array}$ & $\begin{array}{l}\text { Flu, } 150 \mathrm{mg} / \mathrm{m}^{2} \dagger \\
\text { Cy, } 40 \mathrm{mg} / \mathrm{kg} \\
\text { Alemtuzumab, } 1 \mathrm{mg} / \mathrm{kg}\end{array}$ & Grade 3, skin and gut & $\begin{array}{l}\text { Pancreatitis, CMV, renal failure, } \\
\text { HTN, seizures, myelofibrosis, } \\
\text { hyperglycemia }\end{array}$ & 12 & Dead \\
\hline 74 & $108 / \mathrm{F}$ & BMF & $\begin{array}{l}\text { MUD } 4 / 6 \\
\text { CB } \times 2\end{array}$ & $\begin{array}{l}\text { Flu, } 150 \mathrm{mg} / \mathrm{m}^{2} * \\
\text { Melph, } 140 \mathrm{mg} / \mathrm{m}^{2} \\
\text { Alemtuzumab, } 1.5 \mathrm{mg} / \mathrm{kg}\end{array}$ & Grade 3, gut & $\begin{array}{l}\text { cGvHD } \\
\mathrm{EBV}, \mathrm{ADV}\end{array}$ & 13 & Dead \\
\hline \multicolumn{9}{|c|}{ Published cases } \\
\hline $75^{\text {E14 }}$ & 10/M & Infection & $\begin{array}{l}\text { MMUD } \\
\text { PBSC }\end{array}$ & $\begin{array}{l}\text { Flu, } 120 \mathrm{mg} / \mathrm{m}^{2} \dagger \\
\text { Cy, } 40 \mathrm{mg} / \mathrm{kg} \\
\text { ATG, } 15 \mathrm{mg} / \mathrm{kg}\end{array}$ & Grade 2 aGvHD, skin & $\begin{array}{l}\text { cGvHD } \\
\text { EBV-PTLD }\end{array}$ & 26 & Alive \\
\hline $76^{\mathrm{E} 15}$ & $15 / \mathrm{F}$ & $\begin{array}{l}\text { Infection } \\
\text { AIHA }\end{array}$ & $\begin{array}{l}\text { MSD } \\
\text { BM }\end{array}$ & Nil & Nil & Nil & 83 & Alive \\
\hline $77^{\mathrm{E} 15}$ & $18 / \mathrm{F}$ & Infection & $\begin{array}{l}\text { MSD } \\
\text { BM }\end{array}$ & Nil & Grade 4, gut & Nil & 6 & Alive \\
\hline $78^{\mathrm{E} 13}$ & $22 / \mathrm{F}$ & Infection & $\mathrm{BM}$ & NA & NA & NA & NA & NA \\
\hline $79^{\mathrm{E} 13}$ & $101 / \mathrm{M}$ & Infection & BM & NA & NA & NA & NA & NA \\
\hline
\end{tabular}

$A D V$, Adenovirus; $A I H A$, autoimmune hemolytic anemia; $A T G$, anti-thymocyte globulin; $B M$, bone marrow; $B M F$, bone marrow failure; $B u$, busulphan; $C B$, cord blood; $C M V$, cytomegalovirus; $C y$, cyclophosphamide; $F l u$, fludarabine; HTN, hypertension; Melph, melphalan; MFD, matched family donor; $M O F$, multiorgan failure; MUD, matched unrelated donor; MMUD, mismatched unrelated donor; NA, not available; PBSC, peripheral blood stem cells; Treo, treosulfan.

*RIC regimen.

Fanconi or modified Fanconi regimen.

¥MAC regimen. 
TABLE E4. Characteristics of patients with $A T^{E 16, E 17}$

\begin{tabular}{|c|c|c|c|c|c|c|c|c|}
\hline Patient & Age $(\mathrm{mo})$ at $\mathrm{HSCT} / \mathrm{sex}$ & Indication & $\begin{array}{c}\text { Donor/stem } \\
\text { cell source }\end{array}$ & Conditioning & aGvHD & Complications & Follow-up (mo) & Outcome \\
\hline \multicolumn{9}{|c|}{ New cases } \\
\hline 80 & $156 / \mathrm{M}$ & Malignancy & $\begin{array}{l}\text { MSD } \\
\text { BM }\end{array}$ & $\begin{array}{l}\mathrm{Bu}, 1.6 \mathrm{mg} / \mathrm{kg}^{\dagger} \\
\text { Flu, } 180 \mathrm{mg} / \mathrm{m}^{2} \\
\mathrm{Cy}, 40 \mathrm{mg} / \mathrm{kg} \\
\text { Rituximab (dose NA) }\end{array}$ & Nil & $\begin{array}{l}\text { Hemorrhagic cystitis, } \\
\text { VOD, septicemia, } \\
\text { GI bleed }\end{array}$ & 27 & Alive \\
\hline 81 & $8 / \mathrm{M}$ & Infection & $\begin{array}{l}\text { MUD } \\
\text { BM }\end{array}$ & $\begin{array}{l}\text { Treo, } 36 \mathrm{mg} / \mathrm{m}^{2} \\
\text { Flu, } 150 \mathrm{mg} / \mathrm{m}^{2} \\
\text { Alemtuzumab, } 1 \mathrm{mg} / \mathrm{kg}\end{array}$ & Grade 1-2, skin & EBV-PTLD & 6 & Dead \\
\hline 82 & $22 / \mathrm{F}$ & BMF & $\begin{array}{l}\text { MFD } \\
\text { BM }\end{array}$ & $\begin{array}{l}\text { Treo, } 46 \mathrm{~g} / \mathrm{m}^{2} \ddagger \\
\text { Flu, } 150 \mathrm{mg} / \mathrm{m}^{2}\end{array}$ & Grade 3, liver and skin & PTLD, hepatic failure & 20 & Dead \\
\hline 83 & $101 / \mathrm{F}$ & NA & $\begin{array}{l}\text { MSD } \\
\text { NA }\end{array}$ & $\begin{array}{l}\mathrm{Bu}(\text { dose NA) } \\
\mathrm{Cy},(\text { dose NA) }\end{array}$ & Grade 2, skin and gut & MOF & 4 & Dead \\
\hline 84 & $138 / \mathrm{M}$ & Malignancy & $\begin{array}{l}\text { MFD } \\
\text { PBSC }\end{array}$ & $\begin{array}{l}\text { Flu, } 150 \mathrm{mg} / \mathrm{m}^{2} \dagger \\
\mathrm{Cy}, 0.3 \mathrm{mg} / \mathrm{kg}\end{array}$ & Grade (NA), skin & $\begin{array}{l}\text { Extensive cGvHD skin } \\
\text { Interstitial pneumonitis }\end{array}$ & 11 & Dead \\
\hline 85 & $144 / \mathrm{M}$ & Malignancy & $\begin{array}{l}\text { MSD } \\
\text { BM }\end{array}$ & $\begin{array}{l}\mathrm{Bu}(\text { dose NA) } \\
\mathrm{Cy},(\text { dose NA) }\end{array}$ & Grade 2, skin & $\begin{array}{l}\text { Pericardial effusion } \\
\text { Hemorrhagic cystitis }\end{array}$ & 3 & Dead \\
\hline \multicolumn{9}{|c|}{ Updated publication } \\
\hline $86^{\mathrm{E} 16}$ & $54 / \mathrm{M}$ & ALL-T & $\begin{array}{l}\text { MSD } \\
\text { BM }\end{array}$ & $\begin{array}{l}\mathrm{Bu}, 2 \mathrm{mg} / \mathrm{kg} \dagger \\
\text { Flu, } 150 \mathrm{mg} / \mathrm{m}^{2} \\
\text { ATG, } 80 \mathrm{mg} / \mathrm{kg} \\
\text { OKT3 (dose NA)* }\end{array}$ & Nil & $\begin{array}{l}\text { Hemorrhagic cystitis, } \\
\text { CMV reactivation }\end{array}$ & 48 & Alive \\
\hline $87^{\mathrm{E} 17}$ & $22 / \mathrm{M}$ & Infection & $\begin{array}{l}\text { MFD } \\
\text { BM }\end{array}$ & $\begin{array}{l}\text { Treo, } 36 \mathrm{~g} / \mathrm{m}^{2} \$ \\
\text { Flu, } 150 \mathrm{mg} / \mathrm{m}^{2} \\
\text { ATG, } 60 \mathrm{mg} / \mathrm{kg}\end{array}$ & Grade 3, skin and liver & $\begin{array}{l}\text { Fulminant hepatic failure, } \\
\text { gammopathy, EBV } \\
\text { reactivation, encephalopathy }\end{array}$ & 10 & Dead \\
\hline
\end{tabular}

$A L L-T$, T-cell acute lymphoblastic leukemia; $A T G$, Anti-thymocyte globulin; $B M$, bone marrow; $B M F$, bone marrow failure; $B u$, busulphan; $C M V$, cytomegalovirus; $C y$, cyclophosphamide; $F l u$, fludarabine; $G I$, gastrointestinal; $M F D$, matched family donor; $M M F D$, mismatched family donor; $M O F$, multiorgan failure; $M U D$, matched unrelated donor; NA, not available; OKT3, Muromonab-CD3; PBSC, peripheral blood stem cells; Treo, treosulfan; VOD, venoocclusive disease.

*RIC regimen.

$\dagger$ Fanconi or modified Fanconi regimen.

$\$$ MAC regimen. 